
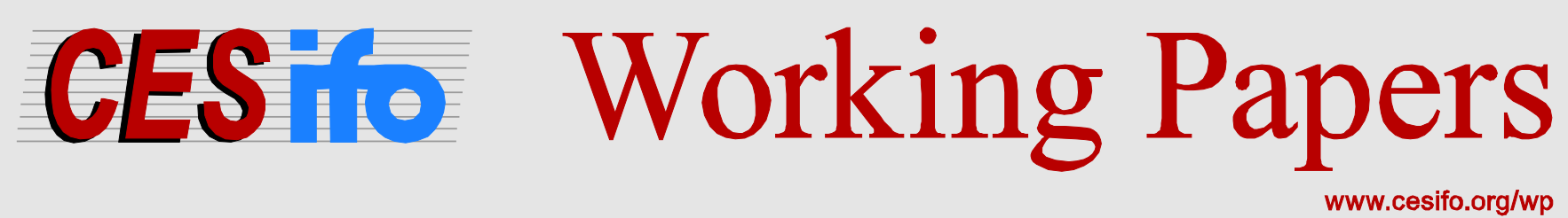

\title{
From Optimal Tax Theory to Applied Tax Policy
}

\author{
Bas Jacobs
}

\author{
CESIFO WORKING PAPER NO. 4151 \\ CATEGORY 1: Public FinANCE \\ MARCH 2013
}
An electronic version of the paper may be downloaded
- from the SSRN website:
- from the RePEc website:
- from the CESifo website:
wWw.SSRN.com
Www.RePEc.org
www.CESifo-group.org/wp

\section{CESifo}




\title{
From Optimal Tax Theory to Applied Tax Policy
}

\begin{abstract}
This paper aims to provide a perspective on the ideal tax system using insights from optimaltax theory supplemented with empirical evidence. These insights are applied to actual policy questions regarding the progressiveness of the labor income tax, in-work tax credits, the design of the capital income tax, the taxation of housing and pensions, the role of indirect taxes, optimal environmental taxes, and corrective taxes on alcohol and tobacco.
\end{abstract}

Bas Jacobs

Erasmus School of Economics

Erasmus University Rotterdam

Rotterdam / The Netherlands

bjacobs@ese.eur.nl

Large parts of this paper are based on a policy paper I have written for the Dutch Ministry of Finance (Jacobs, 2010). This paper has been presented at the The Research Forum on Taxation 'Skatteforum' in Moss, Norway, June 7-8, 2011. I thank the participants, and in particular Agnar Sandmo and Dirk Schindler, for their comments and suggestions. Moreover, I am grateful to Alfons Weichenrieder and two anonymous referees for detailed comments and suggestions, which greatly helped me to improve the paper. The usual disclaimer applies. 


\section{Introduction}

The economic crisis has deteriorated government finances in many countries. Therefore, policy makers seek ways to either cut spending or to increase tax revenues. This paper contains some ideas for fundamental tax reform that could make existing tax systems more efficient and thereby could be of help to raise more public revenue. Although the choice of topics is mainly inspired by many policy discussions in the Netherlands, the insights are relevant for other countries as well.

There is an ongoing on the desirability of the flat tax as the discussion between Mankiw et al. (2009) and Diamond and Saez (2011) demonstrates. In many countries, there are public discussions whether the marginal tax rates for top-income earners should be raised, for example in the Netherlands, the US, and France. Virtually everywhere policy makers are concerned about the adverse effects of the poverty trap on labor-supply incentives at the lower end of the income scale. Many countries have therefore adopted in-work tax credits, such as an EITC, to promote labor-force participation (OECD, 2011a). Since the publication of the Mirrlees Review (2011), the optimal tax treatment of capital income received renewed attention; should there be a tax exemption for the normal return on saving? Some economists advocate no taxation of capital income at all (Mankiw et al., 2009), others argue in favor of some taxation of capital income (Diamond and Saez, 2011), whereas (mainly) law scholars defend a comprehensive income tax where capital and labor incomes are taxed at equal rates. Many governments have generous tax facilities for housing, such as the Netherlands, the US, Norway, Sweden, Denmark and Belgium (OECD, 2011b; Andrews et al., 2011). Mortgage rent is deductible in half of the OECD countries, whereas imputed rent is lightly taxed or not taxed at all (OECD, 2011b). Similarly, in virtually all OECD countries pensioners pay lower or even no social-security contributions (OECD, 2011c). Moreover, in almost all Western countries pension contributions and accrual of (private) pension wealth are tax exempt, whereas pension benefits are taxed (i.e. an 'EET' system) (Yoo and De Seres, 2005). In recent years, many governments have been 'greening' the tax system by shifting the tax burden from labor to consumption of polluting goods. However, is a further greening of the tax system still desirable given the current level of energy taxes and fuel excises?

Most of these policy discussions originate in fundamental questions in the theory of optimal taxation. Therefore, this paper aims to provide a perspective on the ideal tax system using insights from optimal-tax theory. In particular, the government chooses its tax instruments so as to maximize social welfare (defined in a broad sense), while taking into account all relevant tax-induced behavioral responses. The ideal tax system is therefore based on welfare-economic principles. These insights are applied to actual policy questions regarding the progressiveness of the labor-income tax, the design of the capital-income tax and the role of indirect and corrective taxes.

This paper attempts to be both broad in range of topics and go in some depth at the same time. In order to do so, the main focus will be mainly on the efficiency and 
distributional aspects of taxation. Moreover, for the sake of brevity there will be no discussions on the taxation of bequests and corporations. ${ }^{1}$ Furthermore, not much attention will be paid to practical matters of implementation and legal issues. However, this does not imply that these are not important for actual tax design. The range of topics covered in this paper is very broad. In order to remain focused it turned out to be impossible to do justice to all theoretical and empirical research that has been done in various fields.

The setup of this paper is as follows. Section 2 summarizes the main assumptions underlying optimal-tax theory. Section 3 discusses the optimal non-linear income tax. Section 4 argues that a flat tax is generally undesirable. Section 5 presents arguments that taxation of capital income is optimal and discusses some aspects of the taxation of capital income. It will be argued in Sections 6 and 7 that pensions and housing should receive the same tax treatment as ordinary assets. Section 8 analyzes indirect taxes and argues that many indirect instruments are superfluous. Section 9 investigates environmental and energy taxes. Section 10 analyzes corrective taxes on alcohol and tobacco. Section 11 concludes this paper with a summary of policy recommendations.

\section{Assumptions optimal-tax analysis}

This section will thoroughly summarize the most important assumptions that are commonly used in the theory of optimal income taxation (see for example, Diamond and Mirrlees, 1971a,b; Atkinson and Stiglitz, 1976; Mirrlees, 1976). In actual policy debates, these assumptions are not often made explicit. However, the outcomes of the analysis are the logical consequence of the assumptions that are made. Difference of opinion could exist with respect to the empirical validity of some assumptions. A number of assumptions or parameters will be discussed directly in what follows. In any case, criticizing the policy conclusions sketched above ultimately boils down to criticizing the underlying assumptions and the empirical estimates for crucial parameters.

The objective of the government is assumed to be the maximization of social welfare. Welfare is defined in a 'broad' sense, that is, including the value of, for example, leisure time, and environmental quality. Social welfare is a weighted sum of the utilities of all individuals in society. Utility of each individual is determined by a bundle of scarce commodities that each individual consumes: consumption goods, leisure, environmental quality, and so on. In addition, individuals have individualistic and consistent preferences. Individuals exhibit rational behavior, i.e., they maximize their utility subject to their budget constraints. The main source of inequality is that individuals differ in their earning ability, or their 'skill level'. ${ }^{2}$

\footnotetext{
${ }^{1}$ Jacobs (2011) contains some short discussion of these issues. The reader is referred to Boadway, Chamberlain and Emmerson (2010) for an excellent review of the taxation of bequests. Similarly, Auerbach, Devereux and Simpson (2010) and Griffith, Hines and Sørensen (2010) provide in-depth reviews of corporateincome taxation.

${ }^{2}$ Firms often have only a limited role in the analysis. Diamond and Mirrlees (1971a,b) demonstrated
} 
The government chooses its tax instruments to maximize social welfare, while taking into account all relevant behavioral responses of individuals and firms. Indeed, the analysis assumes that the government is an 'enlightened dictator' that is not subject to any political constraints. The government can express its preference for a more equal welfare distribution by attaching a higher marginal weight to individuals with a lower level of utility. Hence, redistribution of welfare from individuals with a high to a low utility is welfare enhancing, since the individual with a high level of utility has a lower marginal social utility than the individual with a low level of utility. ${ }^{3}$ Generally, we will start from the assumption that in the absence of government intervention - markets are efficient. Naturally, social welfare increases if the government corrects market failure, internalizes externalities and provides public goods. In this paper, the focus is on the taxation side and not on the expenditure side of the public budget. Therefore, we will only touch upon these issues when considered relevant.

The welfare-economic approach insists that tax bases should be taxed (or not) only if doing so raises social welfare. Whether some tax bases should be taxed is never determined by ideas about fairness or social justice that are unrelated to individual welfare. This renders the welfare-economic approach sometimes difficult to understand to non-economists. Legal scholars, for example, often have strong (politically and/or subjectively motivated) views on which taxes should be used and how they should be used. However, various ability-to-pay concepts (equal absolute or proportional sacrifice, Schanz-Haig-Simons comprehensive income, consumption/expenditure), references to subjective feelings of 'fairness' or norms originating from philosophical or legal traditions have no role to play in welfare analysis. By maximizing social welfare the government necessarily respects individual preferences. As long as the government attaches a larger weight to the individuals with a lower welfare, maximization of social welfare will produce a more equal welfare distribution. If additional constraints are imposed on the tax system based on some other notion of justice - a notion that is not already present in individual utility - these constraints will necessary lead to lower social welfare. Indeed, in some circumstances, the welfare of all individuals could be reduced by imposing norms of fairness on the tax system. Generally, every superimposition of ad hoc ideas of fairness is superfluous from a welfare-economic point of view and contradicts the Pareto principle (Kaplow and Shavell, 2002).

Nevertheless, it is perfectly feasible that individuals' utility functions do display notions of fairness other than the welfare equality implied by diminishing marginal social utility. Behavioral economics provides many examples: (time-)inconsistent preferences, hyperbolic

that optimal-tax rules are the same in partial and general equilibrium if there is a 100 percent tax on pure profits and if there is perfect substitution of labor types. Although these assumptions may not seem realistic, there is relatively little empirical or quantitative evidence on their importance for optimal-tax rules.

${ }^{3}$ Politicians often consider income or wealth as the ultimate statistic of an individual's well-being, irrespective of the circumstances that this individual lives in. However, in welfare analysis the government does not aim for income or wealth equality per se. This is only desirable as long as this contributes to welfare equality. 
discounting, prospect theory, interdependent utility, and so on. Notions of fairness, equal treatment, status motives, merit motives and paternalism could well be reasons why the standard welfare-economic approach cannot be applicable. However, when deviating from the standard welfare-economic paradigm, it is no longer clear which welfare criterion should be used instead. There are individualistic welfare criteria that allow for inconsistencies in individual preferences and still respect the Pareto criterion in some modified form (Bernheim and Rangel, 2009). Nevertheless, every non-individualistic welfare criterion breaks the link between individual preferences and the objective of the government. Hence, every non-individualistic welfare criterion contradicts the Pareto-criterion (Kaplow and Shavell, 2002). We discuss deviations from the welfarist approach in some specific cases. Nevertheless, it is clear that non-welfarist social objectives are no longer 'neutral' in the sense that the government overrules individual preferences. These impacts should be weighed by politicians in their decision making.

Asymmetric information between the government and the private sector is the most important economic distortion in this analysis. Earnings ability of individuals is private information and cannot be verified by the government (Mirrlees, 1971). Earnings ability can vary stochastically over time or can be influenced by investments in human capital (education, training). Therefore, the government has no access to individualized lump-sum taxes. Indeed, the government can base its tax instruments only on verifiable behaviors of individuals, such as their labor earnings, capital incomes or consumption expenditures. As a result, individuals with a higher earnings ability have incentives to mimic individuals with a lower earnings ability so as to benefit from redistribution geared towards the lower-ability individuals. In other words, high-ability individuals face weaker incentives for working, saving, entrepreneurship and education. Consequently, redistribution results in the wellknown trade-off between equity and efficiency as taxation drives a wedge between the social rewards of an economic activity and the private rewards of that activity.

One can safely assume that governments value horizontal equity in the design of tax policy. ${ }^{4}$ That is, governments do not wish to discriminate between individuals that are identical in 'relevant' characteristics. However, principles of horizontal equity are not neutral as these unavoidably require a judgment regarding the characteristics that are 'relevant'. For example, race, religion, age and gender are not generally accepted as characteristics by which government policy can discriminate. Others, such as family composition, having children, and disability are accepted as criteria for discrimination in policy. A welfare-based approach is blind towards these characteristics. According to the 'tagging principle' (Ak-

\footnotetext{
${ }^{4}$ In this paper, we abstract from the question whether and how differences in household composition should affect tax policy. Individuals have different preferences to cohabit, to work, and to have children. A strict adherence to principles of horizontal equity implies that the government does not wish to discriminate between singles or couples, between households with two income earners or a single income earner, or between households with or without children, as long as these households are identical in relevant characteristics such as earnings or wealth (per person). However, this is not the case in actual policy practice. How optimal tax systems should differentiate between different household types has not been fully crystallized out and the subject of ongoing research.
} 
erlof, 1978) all characteristics that correlate with ability should be included in the design of public policy. In order to avoid inconsistencies or trade-offs between welfare maximization and horizontal equity, we initially assume that individuals have identical preferences and are identical in all other characteristics than income, consumption or wealth. We do not claim any realism in making this assumption. However, this assumption ensures that the government does not base its policy on differences in preferences, but on observable, objective characteristics of households. In addition, the assumption ensures that optimal policy is not dependent either on other characteristics than income, consumption or wealth. Nevertheless, we do in important cases discuss the implications of heterogeneous preferences or other sources of heterogeneity than in earnings ability.

In the remainder, we will generally assume that costs of administration and compliance are identical for all tax instruments and are approximately negligible. Therefore, some tax instruments are not more attractive than others from an administrative point of view. Of course, costs of administration and compliance are neither identical nor negligible across instruments. Nevertheless, these costs are only a fraction of the economic costs of taxation. For example, in the Netherlands, average costs of administration and compliance are only 6 cents per euro revenue (Allers, 1994). At the margin, these costs are probably lower, since the cost of the tax authorities is largely a fixed cost that has to be incurred irrespective of the level of taxation. These costs are only a fraction of the welfare cost of the marginal euro in tax revenue. Jacobs (2009a) summarizes a large literature calculating the cost of taxation. Estimates of the excess burden of taxation are generally in the range of 20-70 percent of marginal public revenue, with some upward outliers of more than 100 percent. Estimates for capital-income taxes are typically larger. Therefore, this paper focuses on the economic costs of taxation.

However, when judging the desirability of various instruments administrative and compliance costs need to be taken into account when necessary, especially in capital-income taxation and commodity taxation. This contribution starts from the assumption that the residence principle can be enforced in the taxation of saving. This has become problematic in recent years. Tax arbitrage and tax planning become easier in more open and international capital markets. Therefore, one needs to take this into account, especially when setting the tax rates on capital incomes. Similarly, the taxation of commodities is becoming more and more subject to international arbitrage and fraud, which diminish tax compliance. This also needs to be taken into account when designing commodity taxes.

\section{Taxation of labor income}

How should the income tax be optimized? Mirrlees' (1971) Nobel-prize winning analysis has shown that it is always optimal to levy a non-linear income tax on labor earnings, irrespective of social preferences for redistribution. Indeed, the marginal tax rate on earnings is never flat. The critical function of the marginal tax rate at any given point in the 
income distribution is to redistribute resources from incomes above that point to incomes below that point in the income distribution. Marginal income taxation (including the impact on marginal tax rates due to income-dependent transfers, tax credits and subsidies) causes efficiency losses on the labor supply of those individuals that are confronted with higher marginal tax rates. At the optimal tax system, marginal taxes are set such that the marginal distributional benefits and the marginal efficiency costs of taxation are equalized.

Social preferences determine the distributional benefits of higher marginal tax rates. Without making explicit statements about the welfare criterion, economists cannot tell how much income should be redistributed, and how high marginal taxes should be. However, model simulations by, amongst others Tuomala (1984), Saez (2001), Jacquet et al. (2010) and Zoutman et al. (2011) demonstrate that marginal tax rates typically follow a Ushape, irrespective of the social preference for redistribution (Diamond, 1998; Saez 2001). ${ }^{5}$ Figure 1 plots the optimal non-linear tax schedules derived by Zoutman et al. (2011) for Rawlsian and utilitarian social preferences and for the cases with an intensive labor-supply margin only and with both an intensive and an extensive labor-supply margin. Indeed, a stronger preference for redistribution implies higher marginal tax rates over the entire income distribution, and generally a bit more so at the lower end of the income scale.

The intuition for the U-shape is as follows. The distributional benefits of a higher marginal tax rate decline continuously as the income level increases. The reason is that, at higher incomes, there will be fewer and fewer individuals paying the higher tax. As revenues are lower, less income can be redistributed. The costs of a marginal tax rate follow the size of the tax base at each point in the income distribution. The distortions of marginal income taxation increase if the number of individuals and/or their earnings increase. Hence, until the modal income level distortions associated with higher marginal income taxes increase as both earnings and densities of individuals with higher earnings are larger. Since distributional benefits decrease and efficiency costs increase, marginal tax rates should decline until the modal income level.

After the modal income level, marginal tax rates could be increasing again, since tax bases might shrink. Indeed, the density of individuals with a higher income is smaller if the income level is higher. This reduces the tax base. However, their earnings increase, which increases the tax base. The net effect on the tax base is unclear. Indeed, Boadway and Jacquet (2008) demonstrate that if the government has Rawlsian, maximin preferences, marginal tax rates could be continuously declining with income as long as the skill distribution has a declining relative hazard rate. Hence, the optimal non-linear structure of income taxes is critically determined by the shape of the skill distribution. For most empirical income distributions, the distributional benefits of higher marginal taxes above modal income appear to be declining at a slower rate than the efficiency costs, hence marginal

\footnotetext{
${ }^{5}$ The most advanced simulations in the literature employ the empirical earnings distribution to distill the non-observed ability distribution in the population, supplemented with estimates of Pareto-tails for the top-income earners (Saez 2001; Jacquet et al. 2010; and Zoutman et al., 2011). Earlier papers in the literature assumed less realistic synthetic skill distributions (Mirrlees, 1971; Tuomala, 1984).
} 
Figure 1: Examples of optimal non-linear taxes

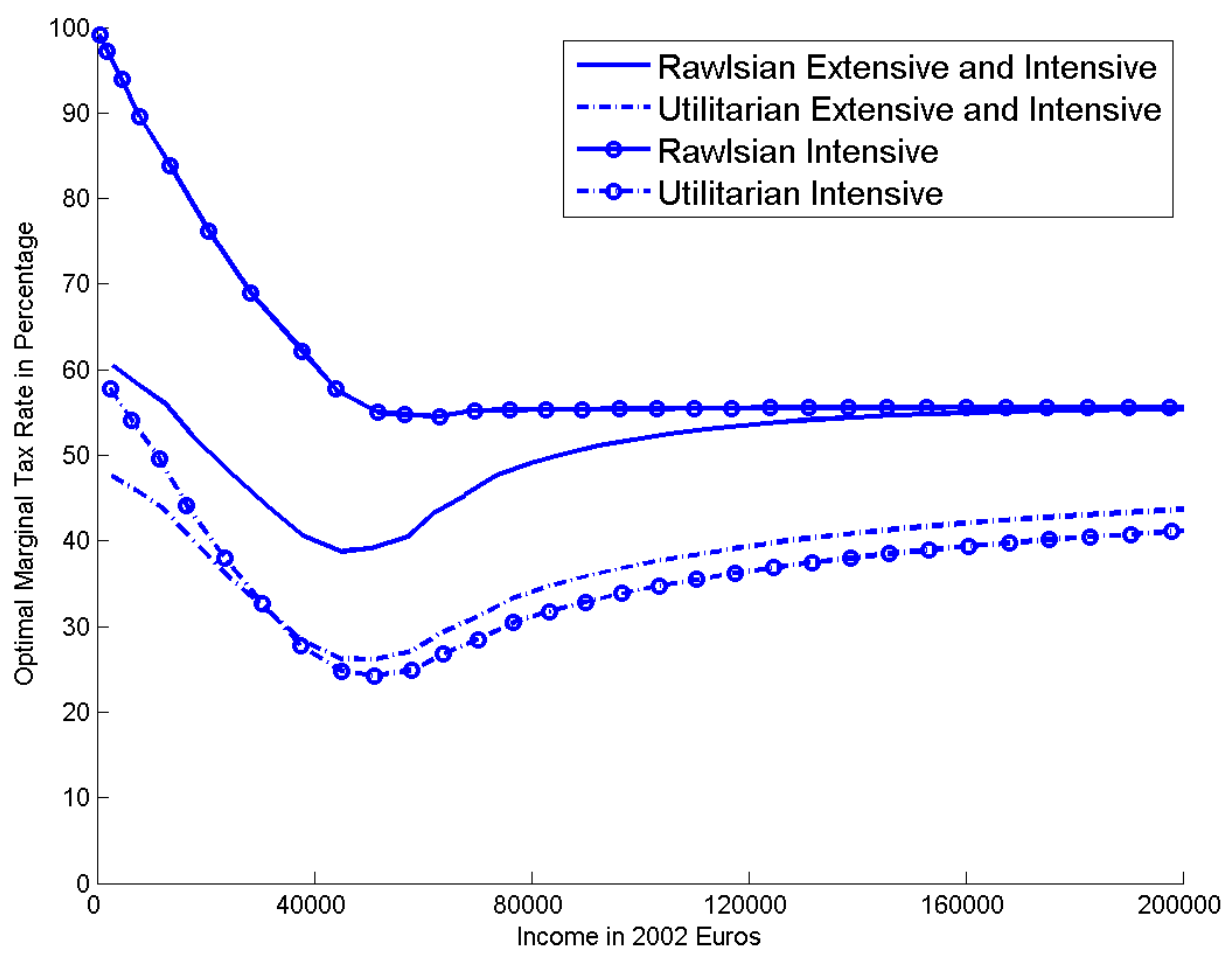

Key: Simulations with an intensive margin only employ the Mirrlees (1971) model. The simulations with an extensive and intensive margin are based on Jacquet et al. (2010), which merges Mirrlees (1971) with Diamond (1980). Households maximize a separable utility function with constant elasticities in consumption and labor, and a separable, discrete participation cost. Non-observed distributions of earning ability and participation costs are estimated using a structural labor supply model with carefully reconstructed individual budget constraints based on the Dutch tax-benefit system. The skill distribution is supplemented with direct estimates of the Pareto parameter (3.35) for the top tail of the income distribution. The simulations assume an uncompensated wage elasticity of labor supply of 0.25 and an income elasticity of 0.1 . The average participation elasticity is 0.57 in simulations with an extensive margin. Source: Zoutman et. al (2011). 
taxes are increasing (Diamond, 1998; Saez, 2001; Zoutman et. al. 2011). In addition, the marginal tax rate after modal income is also determined by the social desire to redistribute income. The average distributional benefit of taxing individuals with higher incomes increases, since the utility loss inflicted on the individuals paying higher taxes diminishes as the income level rises (Diamond, 1998). Hence, marginal tax rates rise after modal income if the government cares relatively more about the middle-income groups. Only for the Rawlsian social welfare function this is not the case, since the utility loss on all tax-paying individuals is not valued at all.

The U-shape of optimal marginal tax rates often confuses policy makers and politicians, but makes perfect economic sense. Again, it is noted that the function of marginal tax rates is to redistribute income from high-income earners to low-income earners. If the social desire for redistribution increases, marginal tax burdens should increase for the lowincome groups so as to raise the average tax burden on the high-income groups. Confusion arises because average and marginal tax burdens are often interchanged, but these are very different concepts. Similarly, and just as confusingly, when the social desire to redistribute incomes diminishes, the marginal tax rates should decline, and the more so at the bottom end of the income scale. Then, the average tax burden for middle and higher income groups falls.

Rising marginal tax rates after modal incomes make sense only if the middle-income groups have a substantial weight in social welfare. It is again paradoxical that especially the left-wing parties often want to increase the marginal tax burden after modal incomes, whereas the right-wing parties want the opposite. The left-wing parties thus pursue less 'Rawlsian' type of tax policies than the right-wing parties.

The optimality of sharply declining marginal tax rates from low to middle-income groups are an important argument against universal programs that are observed in Scandinavian welfare states, i.e. welfare state arrangements that are provided to all individuals irrespective of their earned income, such as flat-rate benefits for pensions or other forms on non-employment, or universal (often costless) access to health care, child care, and education. As universality implies that middle and high-income groups also benefit from redistribution, the labor market is distorted much more severely, since marginal tax rates are on average much higher so as to finance universal public programs.

The optimal marginal top rate in the income tax can be computed analytically. Empirically, the top tail of the earnings distribution is described best by the Pareto distribution (Atkinson et al., 2011). If income effects are absent, the revenue-maximizing top rate in the highest tax bracket equals $\tau=(1-g)[1-g+\alpha \varepsilon]^{-1}$ where $g<1$ is the social marginal welfare weight for top-income earners, $\varepsilon$ is the (un)compensated elasticity of taxable income, and $\alpha$ is the Pareto parameter of the earnings distribution (Saez, 2001). $g$ measures the social value in euro's of transferring an additional euro to an income earner in the top-tax bracket. Rawlsian social preferences imply that the government wants to 'soak the rich', i.e., $g=0$. In that case, the tax rate is optimally set at the top of the Laffer curve. More generally, one expects the social valuation of income for the very high income earners 
Table 1: Revenue-maximizing top rates for a selection of countries

\begin{tabular}{l|rrrrr}
\hline \multirow{2}{*}{ Country } & Pareto $^{\text {Earfective }}$ & \multicolumn{3}{c}{ Optimal top rate } \\
\hline Australia & 1.89 & 0.45 & 0.64 & 0.78 & 0.54 \\
France & 2.54 & 0.62 & 0.57 & 0.72 & 0.47 \\
Germany & 1.61 & 0.47 & 0.67 & 0.81 & 0.58 \\
Netherlands & 3.35 & 0.54 & 0.50 & 0.67 & 0.40 \\
Spain & 2.04 & 0.40 & 0.62 & 0.77 & 0.52 \\
United Kingdom & 1.77 & 0.52 & 0.65 & 0.79 & 0.56 \\
United States & 1.58 & 0.43 & 0.68 & 0.81 & 0.58 \\
\hline
\end{tabular}

${ }^{a}$ Pareto parameters apply to most recent estimates (2007-2010) and were extracted from the World Top Incomes Database: http://topincomes.g-mond.parisschoolofeconomics.eu/, except for the Netherlands (2006), which comes from Zoutman et al. (2011a).

${ }^{b}$ Top rates are the total tax wedges (including employer contributions) in 2011 on the incomes of a single worker earning $167 \%$ of the average wage and are taken from the OECD http://www.oecd.org/tax/taxpolicyanalysis/Table. Indirect taxes apply to 2003-2006 and are taken from OECD (2011): http://dx.doi.org/10.1787/888932482688. Effective top rates are calculated as $\frac{\text { top rate }+ \text { indirect tax }}{1+\text { indirect tax }}$.

to go to zero in the limit if the marginal social value of income is declining.

Table 1 provides revenue-maximizing tax rates for top-income earners for a selection of countries. Tax rates for top-income earners are generally set below the revenue-maximizing level for the baseline elasticity of $\varepsilon=0.3$, except for the Netherlands and France. The revenue-maximizing top rate is generally around 60-65 percent, except in the Netherlands where it is around 50 percent, due to a very thin tail of the earnings distribution.

It does not make a lot of economic sense to introduce a separate top bracket for the very high-income earners as many politicians suggest. The simulations of optimal schedules demonstrate that tax rates increase much earlier (Saez, 2001; Zoutman et al. 2011). The function of a higher marginal tax rate is to redistribute income from very high income earners to everyone below the high-income earners, including the not-as-high-income income earners. Since social valuations of income among high income earners should be small and very similar, the social value of such redistribution should be regarded as very small, while it does distort behavior at the top-income earners. Hence, it does not make economic sense to promote an increase in the marginal tax rate at very high income levels. Hence, a separate top bracket for very high income levels cannot be defended on welfarist grounds. Effective income redistribution requires that the top rate is increased at a much lower level of income, somewhere after modal income.

Non-welfarist motives could justify a separate top bracket or a very high effective marginal tax rate for the top-income earners. The optimal marginal tax rates are derived under the assumption that individual preferences are individualistic. However, behavioral economics has given a number of reasons why optimal marginal taxes could either be lower 
or higher. If consumption is a status good, causes rivalry or induces keeping-up-with-theJoneses' effects, then individuals - in the absence of taxation - tend to supply too much labor and this causes status or rat races (Akerlof, 1976; Layard, 1980; Kanbur et al. 2006). Marginal taxes then help to internalize these negative externalities, so that the economic cost of taxation is lowered. However, also leisure can be a status good (Alesina et al., 2005) or high leisure consumption could erode work ethic (Lindbeck and Nyberg, 2006). In that case labor taxation is even more distortionary. The net effect of these behavioral economic aspects is unclear and should be weighed by politicians.

A substantial poverty trap with marginal tax burdens in the order of 60-70 percent is unavoidable, see also Saez (2001), Jacquet et al. (2010), Zoutman et al. (2011). High marginal tax burdens at the lower end of the income scale ensure that income support for the poor is phased out and that the middle and higher income groups start contributing to redistribution. Only by having a high marginal tax burden at the low-income groups, the average tax burden for these groups can be lowered. Or, in other words, it is not generally possible to reduce the poverty trap without reducing poverty alleviation.

Marginal tax rates higher than 100 percent are generally never optimal (Mirrlees, 1971). In many countries it is still the case that examples can be found where marginal tax burdens are larger than 100 percent due to the cumulation of means-tested income support, income-dependent subsidies, tax credits and marginal tax rates (OECD, 2011a). However, Zoutman and Jacobs (2012) demonstrate that this could be an optimal policy in the presence of costly monitoring of work effort (or ability). Monitoring of work effort provides an implicit subsidy on work, partially offsetting the explicit tax on work. Nevertheless, effective marginal taxes larger than 100 percent should preferably be avoided, especially if the government does not monitor work and job-search efforts of non-participants.

Besides the intensive labor supply response, individuals also respond on the extensive labor-supply margin, see Blundell et al. (2011). The average, not the marginal, tax rate drives the participation choice. Indeed, the larger is the average level of taxation, the more participation will be discouraged. Zoutman et al. (2011) show that including the extensive margin in the optimal non-linear tax framework does not change its qualitative shape. However, marginal tax rates are lower and the U-shape is more pronounced, see also Figure 1, where the optimal tax schedule is also depicted with intensive and extensive labor supply responses for Rawlsian and utilitarian governments. As can be seen, the optimal tax rate generally decreases. The effect at the bottom is quite large and the effect at the top is negligible. Since the participation margin has the strongest impact at the lower end of the income scale, marginal tax rates should be especially lowered at the bottom end of the income distribution.

An important question is whether participation should be taxed or subsidized on a net basis. Diamond (1980) and Saez (2002a) have demonstrated that EITC-type of programs could be optimal if the welfare weight attached to the working is larger than unity. A Rawlsian government would never want to use participation subsidies, since these subsidies imply a redistribution from the non-working to the working population. Indeed, participa- 
tion should then be taxed on a net basis. Christiansen (2012) demonstrates that the use of participation subsidies is mainly associated with raising efficiency, as EITC programs imply reverse redistribution from the non-workers to the working population. By providing a participation subsidy, the adverse consequences of income redistribution on labor-force participation are alleviated. Jacquet et al. (2010) and Zoutman et al. (2011) demonstrate for the US and the Netherlands, respectively, that participation is subsidized only on a net basis using utilitarian social objectives. Moreover, an EITC is optimal only at the very low skill levels.

It often seems feasible to reform the tax system such that it becomes more efficient in redistributing income. De Mooij (2008) using the MIMIC model of CPB Netherlands Bureau for Economic Policy Analysis demonstrates that it is feasible in the Netherlands to introduce EITC's that do not harm employment, but do redistribute more income towards the working poor at the same time. Also, Zoutman et al. (2011) demonstrate for the Netherlands that the current tax system probably features too low marginal tax rates for the lowest income groups as the optimal rates are always found to be above the actual rates at the lower end of the income scale. Hence, too little income is redistributed towards the poor. Blundell and Shephard (2012) find exactly the same for the UK.

From a non-welfarist perspective, redistribution towards the working poor rather than the non-employed could also be desirable (Kanbur et al., 2006). If having work per se has social value, a too high tax burden at the lower end of the income distribution may well cause too high levels of non-participation. However, the price of supporting the working poor is less redistribution towards the non-working poor.

Typically, tax authorities do not allow for negative income taxes. This erodes the redistributive powers of the tax system considerably, as general tax deductions and credits cannot be targeted to individuals or households with very low or zero taxable incomes. Consequently, alternative ways to reach low-income individuals are devised. Examples include subsidies (e.g., rent assistance, health care), public provision of private goods, or other transfers in kind. However, such measures typically distort the consumption patterns of households. In addition, many tax payers may need to apply for these additional incomesupport schemes. As a general principle - exceptions are discussed later in the section on commodity taxation - it is better to directly target income support to the poor by making a negative income tax available, rather than transferring resources to the poor indirectly. The latter causes inefficiencies in consumption patters, which can be avoided by direct transfers. Moreover, providing direct income support through the income tax system instead of using indirect schemes can bring substantial cost savings in administration and tax compliance.

In many European countries collective labor agreements negotiated by unions and minimum wage legislation effectively impose a wage floor in labor markets, which results in involuntary unemployment. Minimum wages are probably not a very efficient redistributive device (Gerritsen and Jacobs, 2011, 2012). ${ }^{6}$ Minimum wages push low-skilled workers out

\footnotetext{
${ }^{6}$ Gerritsen and Jacobs $(2011,2012)$ avoid the informational inconsistency in Allen (1987) and Guesnerie
} 
of the labor market, and provide incentives to become high-skilled so as to avoid low-skilled unemployment. Low-skilled workers that become unemployed cease to pay taxes and start collecting benefits. Moreover, they suffer a utility loss if they are involuntarily unemployed. The additional revenue from having more high-skilled workers is typically not sufficient to off-set this. In addition, high wage floors promote work in the informal economy or black market, which is generally ignored in the literature. It is often better to provide 'income support' rather than 'price support'. Minimum net income levels can be sustained using wage subsidies or an EITC, while at the same time reducing the minimum gross wage for employers. Such a reform does not cost much public revenue as the government saves on unemployment and welfare benefits, and discourages black-market employment.

The optimal shape of the tax structure has been derived under the assumption that there was no market failure in labor or capital markets. However, labor markets could be distorted by unions, search-frictions, efficiency wages, and insider-outsider considerations. There is an active area of current research exploring the consequences of labor market frictions for optimal income taxation, see the excellent overview in Boadway and Tremblay (2012). Whether labor market distortions should increase or decrease optimal marginal tax rates is a priori unclear. This depends on the many particulars of the labor market in question.

Apart from redistribution, redistributive income tax systems also help to insure labor market risks (Eaton and Rosen, 1980a). Simulations presented in Eaton and Rosen (1980b) demonstrate that optimal marginal tax rates substantially increase when there is noninsurable income risks, in the order of 10 percentage points higher marginal taxes. However, in the calculations discussed above, marginal tax rates are based on observed samples of individuals. In the data it is impossible to distinguish individuals that have a low income due to low ability or due to bad luck. Hence, the insurance gains are at least partially captured in the calculations of optimal taxes above.

In addition, redistributive tax systems may be helpful to relax credit constraints by redistributing resources from non-constrained to constrained individuals, see also Jacobs and Yang (2012). Hence, the labor-income tax helps to correct failures in capital markets. Jacobs and Yang (2012) and Hubbard and Judd (1986) demonstrate that optimal marginal tax rates could be substantially higher by correcting capital market failures. However, from a practical point of view it is probably more useful to address these liquidity constraints directly by providing borrowing facilities rather than making the tax system more progressive.

and Roberts (1987) that the government needs to observe wages to implement the minimum wage and does not use this information in setting income taxes. Moreover, Gerritsen and Jacobs (2012) allow for a completely general rationing scheme, of which Lee and Saez (2012) is a specific, knife-edge case. 


\section{Flat income tax not desirable}

Friedman (1962) was among the first to propose a flat tax. ${ }^{7}$ Thereafter, Hall and Rabushka (1983) greatly popularized the idea. Recently, Mankiw et al. (2009) also argued in favor of a flat tax. ${ }^{8}$ In many countries many politicians and some economists propose to introduce a flat tax rate on labor earnings that replaces the progressive rate structure, while maintaining a general tax credit. Often, it is argued that the effective marginal tax burden after taking into account income-dependent tax credits, tax deductions, subsidies, etc. - is virtually flat (see for a Dutch example Gielen et al., 2009). Hence, introducing a flat tax and removing all the tax deductions, tax credits, tax subsidies, and so on, leaves the effective marginal tax burden (and therefore the amount of income redistribution) unaffected. Often, there is confusion about what a flat tax really is. Most proposals consider a flat rate income tax, while leaving tax deductions, income-dependent tax credits and subsidies, and so on, in tact. Then, there is no real flat tax, since effective marginal tax rates are still (highly) non-linear and most of the supposed advantages of a flat-rate tax structure emphasized by its proponents will not materialize.

Of course, it is a very good idea to clean up the tax system thoroughly by removing undesirable tax arrangements, eliminating illogical exceptions and closing loopholes. The proceeds can be used to lower marginal tax rates. If the income effects are neutralized by appropriate adjustments of the tax rates or general tax credits, such an operation yields a genuine welfare gain - provided of course that many exceptions and tax provisions have no direct economic value. This is where everyone would agree with Hall and Rabushka (1983) and many others. However, a flat tax rate can never be seen as the ultimate goal of a reform to simplify the tax system. Indeed, the structure of tax rates are the ultimate consequence of redistributional objectives, see previous section.

The most important argument put forward in favor of a flat tax is that a non-linear tax system opens up opportunities for arbitrage and income shifting between tax payers, over time and across tax bases. In particular, households would like to shift income towards the person with income in the lowest tax bracket. Hence, increasing marginal tax rates provide incentives to households to smooth labor supply among partners within a household so that a distortion in the allocation of time between partners within the household results (see,

\footnotetext{
${ }^{7}$ A flat tax is referred to as a tax system with a linear tax rate on labor income with a general tax credit, a general tax exemption, or even a refundable, general tax credit (a negative income tax). Often, the flat labor tax is combined with a zero tax on capital income or a zero tax on the normal return on capital income. In any case, the critique of the flat tax in the main text applies to all these different flat-tax proposals.

${ }^{8}$ The analysis of Mankiw et al. (2009) suggests that a flat income tax could be roughly optimal. However, this conclusion is based on the empirically unwarranted assumption that top tail of the income distribution is log-normally distributed. These authors argue that the differences between the log-normal and Pareto distribution are negligible. However, the tails of empirical earnings distributions are too thin when approximated by a log-normal distribution, especially at the very high-income levels. See also Atkinson et al. (2011) and the discussion in Diamond and Saez (2011).
} 
for example, Bovenberg and Teulings, 2006). Given that primary earners (mainly men) earn on average more than secondary earners (mainly women), this argument appears to be quite strange. The distortion created by a non-linear tax system on the allocation of time would imply that primary earners would be doing inefficiently large amounts of household production, whereas secondary earners would do inefficiently little household production. I am not aware of any empirical evidence supporting this claim. However, it is conceivable that some correction in the time-allocation between primary and secondary earners could be socially desirable, since the incidence of household tasks is still typically very skewed towards women. Moreover, even if there are distortions in the time allocation within households, this is probably second-best efficient, since secondary earners have much higher labor-supply elasticities than primary earners (Blundell and MaCurdy, 1999; Meghir and Phillips, 2010; Blundell et al. 2011). The Ramsey principle then insists on taxing secondary earners at a lower rate than primary earners (Boskin and Sheshinski, 1983). However, as long as this is impossible, and primary earners earn more on average than secondary earners, it is second-best desirable to have some distortion in the time-allocation of households through increasing marginal tax rates so as to smooth labor-supply distortions over primary and secondary earners.

A non-linear income tax creates possibilities to shift income over time. Individuals typically have a lower taxable income during retirement than during working age. Hence, a non-linear tax schedule would provide incentives to save for retirement if the government allows individuals to deduct their retirement savings from the income tax, as is the case in many countries (OECD, 2011c). The question is, however, how important these distortions are, since in many instances the level of tax-favored pension saving is determined by the institutional setting. For example, in the Netherlands all workers covered by a collective labor agreement (about 80 percent of work force) are obliged to save for occupational pensions and can neither choose their desired level of pension saving nor the pension fund in which to save. Similarly, self-employed with risky incomes have incentives to realize profits in bad times when earnings are low, and defer profit realization when earnings are high. In principle, this type of tax shifting provides income insurance, which is valuable to the self-employed (see Eaton and Rosen, 1980a, 1980b). Empirical evidence by Kleven et al. (2011) indeed suggests that tax evasion is important for self-employed. Whether the erosion of the tax base is larger than the insurance gain is not clear.

Finally, a non-linear labor-income tax gives incentives to transform labor into capital income if the latter is taxed at a lower rate, especially for the self-employed. This mechanism is empirically well-established (see for example Fuest and Weichenrieder, 2002 and De Mooij and Nicodème, 2008). However, this form of arbitrage is inevitable if one wishes to tax capital incomes at a lower rate than labor incomes. Introducing a comprehensive income tax where capital incomes are taxed at the same rate as labor incomes eliminates any arbitrage between tax bases of labor and capital income, but cannot be defended on welfare-economic grounds. This paper will argue below that a dual-income tax is indeed optimal. Hence, there will always remain incentives to shift income to tax bases where 
taxes are lower. One can only try to reduce the possibilities for arbitrage by reducing the number of tax bases, for example, by introducing one, integrated regime for taxing capital income that treats all sources of capital income symmetrically - see also below. In addition, tax authorities should try securing the division between labor income and capital income by attributing a fictitious return on capital invested in closely-held companies or small enterprises. This is already common practice in Norway (Sørensen, 2009). Avoiding arbitrage between capital and labor incomes requires that top labor-tax rates should not deviate too much from effective tax rates on capital incomes of firm owners, not that the rest of the labor tax rates should be flat.

In principle, a flat tax avoids all these forms of arbitrage. However, this is the case only if all effective marginal tax rates are in fact flat. Thus, as long as not all income-dependent measures in the entire tax-benefit system are eliminated, effective marginal tax rates are not flat, and tax arbitrage will potentially remain a problem.

A number of fallacious arguments are often put forward by proponents of a flat tax. Many politicians argue that a flat tax is more efficient than a non-linear income tax. Even Hall and Rabushka (1983) claim that a flat tax generates more employment. However, the discussion of the optimal non-linear income tax suggested that this is a flatly incorrect argument. The equity-efficiency trade-off stems from the informational constraint in verifying individual earnings ability. The government can only observe earnings, but labor effort and earnings ability are private information. Nevertheless, individual earnings correlate with individual earning ability. The flat tax employs no information on individual earnings, only on aggregate earnings. Hence, costly information is not used and the equity-efficiency trade-off worsens. ${ }^{9}$ Consequently, with a linear income tax the government can redistribute fewer resources at the same efficiency cost, or it has to tolerate more dead-weight loss to achieve the same income redistribution as under a non-linear income tax. Hence, pleas for a flat tax should be discarded on the basis of fundamental economic logic.

Saez (2001) and Zoutman et al. (2011) demonstrate that optimal marginal taxes under a flat tax can easily be 10 percentage points higher than the average of optimal marginal tax rates under a non-linear income tax. Zoutman et al. (2011) calculate that the welfare difference between the optimal flat tax and the optimal non-linear tax amounts to $0.5 \%$ of gdp for utilitarian social preferences to about $9 \%$ of gdp for Rawlsian social preferences. The more redistributive is the social objective, the more the flat tax will be a straitjacket.

Moreover, if the government introduces a flat tax, then it becomes socially desirable to use indirect instruments in order to partially remedy the inefficient redistribution via the labor-income tax. The government then wishes to introduce taxes on commodities that are consumed disproportionally by the rich and subsidies on commodities that are disproportionally consumed by the poor. Think of rent assistance and health subsidies. These indirect instruments do cause additional distortions in consumption behavior, which can be

\footnotetext{
${ }^{9}$ This logic is the same as the logic underlying the non-optimality of universal government support systems that do not condition public services or benefits on individual income. With universality, the government does not employ information on individual earnings capacity.
} 
avoided by only taxing earnings non-linearly - see also the section on commodity taxation. Similarly, when the government has only access to flat income taxes, and environmental taxes fall disproportionally on the poor, the optimal corrective tax will be set below the Pigouvian level so that and the environment is harmed. This can be avoided by taxing income non-linearly - see also the section on corrective taxation.

Many proponents claim that a flat tax makes the tax system simpler as every tax payer would know her marginal tax rate. Again, this is a fallacy. Even under a fully non-linear income tax (with a potentially infinite number of tax brackets) tax payers can use a tabular provided by the tax authorities that gives marginal tax rates, average tax rates and total tax payments at each level of taxable income. Once taxable income is known, it's very simple to figure out the marginal and average tax rate. The complexity of the tax system is not caused by the rate structure, but by the complications in determining taxable income. This is where Hall and Rabuschka (1983) oversell their case. Taxable income is difficult to determine due to deductions, tax credits, income-dependent subsidies or income support, exceptions to tax rules, loopholes in the tax law, and the correct application of tax laws. A flat tax rate does not change anything about the complexity of the tax code if nothing is changed in the determination of taxable income.

Sometimes it is also suggested that the flat tax can be implemented as a payroll tax at the firm level. Consequently, firms do not need to keep track of individual characteristics on which the current pay-roll tax is based. As a result, the administrative burden on firms can be reduced. In addition, the flat payroll tax may serve as a final withholding income tax for households. Filing a tax return at the household level would then become superfluous. Hence, the government can make substantial savings on administrative and tax collection costs. However, the withholding tax can never function as a final tax if not all income-dependent tax credits, exemptions, deductions, and so on, are abolished. Indeed, no cost savings can be made if all households need to file a tax return after all. Basically, introducing a flat rather than a non-linear pay-roll tax only shifts the administrative burden from firms to households, but does not reduce it. Moreover, Kleven et al. (2011) demonstrate that firms have an important role as third-party reporters to the government so as to reduce tax avoidance and tax evasion. Reducing or eliminating this role of firms will therefore be costly because tax avoidance and evasion will increase.

Finally, some proponents of a flat tax claim that there will be less political fiddling with taxes to serve special interests (Hall and Rabuschka, 1983; Bovenberg and Teulings, 2006). Again, this argument is weak. Tax rates can not easily be used for political manipulation. Tax-rate changes are too costly and too transparent to voters. Moreover, the politicians have the ultimate say over tax rates. In practice, politicians serve special interests with exceptions to tax laws, new tax credits or deductions, tax privileges for certain groups of voters, and so on. Introducing a flat tax rate will not change this practice. 


\section{Taxation of capital income}

Should capital income be taxed, and if so, how? The optimal-tax literature provides two anchor points arguing that capital incomes should not be taxed at all. These arguments provide the normative basis for proposals to exempt (the normal return to) savings from taxation, see, for example, Mankiw et al. (2009), Banks and Diamond (2010), the Mirrlees Review (2011), and Diamond and Saez (2011).

The first point of reference is Chamley (1986) and Judd (1985). In these analyses households are infinitely lived or they form dynasties of altruistic generations that are perfectly linked with each other through bequests (cf. Barro, 1974). Labor, capital and insurance markets are perfect and frictionless. A positive tax on capital income can then be seen as an exponentially increasing marginal tax rate on consumption further away in the future. Such a policy clearly violates Ramsey principles. In order to avoid an infinite marginal tax burden on consumption in the far future, capital incomes should therefore be taxed only in the 'beginning of times' and never in the long run.

The second point of reference is the well-known theorem of Atkinson and Stiglitz (1976). If preferences of households are weakly separable between leisure and consumption, then it is not optimal to tax capital income if the government can levy a non-linear income tax. Intuitively, weak separability implies that consumption profiles chosen by households are not dependent on labor supply behavior. Hence, taxing capital income cannot help to reduce the distortions created by labor-income tax, but do distort saving behavior. Consequently, it is better not to tax capital incomes. This result is independent from the issue whether households have a finite or infinite horizon.

Nevertheless, both these corner stones in public finance are very stylized and too stylized to permit the conclusion that capital income should not be taxed at all. Households do not have an infinite time horizon as in Chamley (1986) and Judd (1985). Neither can they be represented by a altruistic dynasty of households that are perfectly connected through a chain of bequests. In addition, one can question the separability of preferences needed to apply the Atkinson-Stiglitz theorem. Further, individuals do not only save in the form of financial capital, but also in the form of housing, human capital and firm ownership. Finally, financial markets may not work perfectly, since individuals might be liquidity constrained or find it impossible to insure risks in their labor income.

The rest of this section argues that capital incomes should be taxed for both efficiency and equity reasons. Although capital-income taxes imply intertemporal distortions in saving decisions, they can help to reduce the distortions created by the labor-income tax. In particular, capital-income taxes boost labor supply, increase the retirement age, help to contain tax-arbitrage, promote investments in human capital, and tax pure rents. In addition, capital-income taxes can be helpful in complementing the labor-income tax to redistribute resources and to insure labor income risk. Finally, capital-income taxes are generally desirable when capital and insurance markets fail. 


\section{Capital-income taxes alleviate labor-supply distortions}

By taxing capital income, the government could implicitly tax leisure, which then helps to offset the distortion of labor-income taxation on labor supply. Hence, capital taxes could be useful for efficiency reasons. Generally, consumption rises and labor supply falls with age. Labor supply falls if individuals work fewer hours or stop participating, for example, due to (early) retirement. This pattern suggests that consumption at higher ages becomes relatively more complementary to leisure than consumption at young ages. One should be careful to conclude that the observed pattern of consumption and leisure is a necessary condition for complementarity between consumption and leisure in the utility function. This is only the case if the marginal willingness to save increases with leisure time demanded. In that case, the Atkinson and Stiglitz (1976) results imply that savings should optimally be taxed. A positive capital tax reduces labor supply of the younger and boosts labor supply of the older workers through intertemporal substitution in leisure. If the increase in labor supply of the 'old' more than compensates the reduction in labor supply of the 'young', total labor supply over the life cycle increases, and a positive capital tax is optimal. In common macro-economic models this is the case as Erosa and Gervais (2002) and Conesa et al. (2009) have demonstrated. Indeed, these authors find substantial optimal taxes on capital incomes. Pirttilä and Suoniemi (2010) use Finnish consumption data and demonstrate that (average) labor supply significantly falls when individuals have larger capital incomes.

Households do not only save in the form of financial capital. For many households, savings are made in the form of paying off mortgage debt on owner-occupied housing. Pirttilä and Suoniemi (2010) demonstrate also that higher expenditures on housing also reduce labor supply.

No direct estimates of the effects of capital-income taxes on retirement are available. However, we do know that retirement decisions respond strongly to financial incentives (Gruber and Wise, 1999, 2002). Since capital-income taxes erode accumulated pension wealth, they stimulate later retirement (Jacobs, 2009b). As long as retirement choices are distorted due to explicit or implicit taxes on continued work, it is therefore optimal to have positive capital-income taxes to counter these distortions in retirement.

\section{Capital-income taxes reduce distortions on human capital}

By taxing labor income at non-linear rates, the government potentially reduces the return to investments in human capital (education and training). The most important costs of such investments are the forgone labor earnings, which are taxed. Besides forgone earnings individuals have to invest resources for books, tuition, and other materials. The government could make human capital investment decisions efficient by making all costs of the investment effectively deductible against the rate at which future earnings are taxed. Bovenberg and Jacobs $(2005,2011)$ demonstrate that this is also an optimal policy under 
some separability conditions in the gross earnings function.

However, not all costs of education can be verified by the government. Therefore, not all costs can be made tax deductible or can be subsidized. Think of the costs of effort and working hard as a student, parental investments in children, and training of employees. A large part of human capital investments are informal (Carneiro and Heckman, 2003). The costs of on-the-job training and working careers are for the larger part non-verifiable costs of effort. All these costs cannot be subsidized either. A high skill-premium moreover suggests that returns to human capital may compensate for substantial immaterial costs of effort (Jacobs and Bovenberg, 2010).

Jacobs and Bovenberg (2010) show that it is optimal to tax capital income to reduce the distortions of the labor-income tax on human capital investment. By taxing capital income the government provides an implicit subsidy on human capital investments as individuals substitute financial for human savings. They make a back-of-the-envelope calculation using a stylized life-cycle model and derive that the optimal tax rate on capital income is close to the optimal tax rate on labor income. This holds true even if a substantial fraction of investments in human capital is verifiable and can be subsidized directly. Hence, capital incomes should be taxed if the tax on labor income distorts investment in human capital. ${ }^{10}$

\section{Capital-income taxes reduce arbitrage between capital and labor income}

Capital income should be taxed as well to avoid arbitrage between labor and capital tax bases. The self-employed get stronger incentives to start a closely-held firm and being paid out in the form of capital income if taxing labor income with progressive tax rates reduces the return to being self-employed. Indeed, if capital incomes would not be taxed, there would be very strong incentives to transform labor earnings into capital incomes. Taxing capital incomes is therefore necessary to avoid tax-arbitrage between labor and capitalincome tax bases and to maintain the integrity of the income-tax system (Christiansen and Tuomala, 2007; Reis, 2009). Fuest and Weichenrieder (2002) and De Mooij and Nicodème (2008) demonstrate that these arbitrage-effects can be important empirically. This argument does not imply, however, that capital income should be taxed at the same rate as labor income.

\section{Capital-income taxes tax pure rents}

From optimal-tax theory it is well-known that it is optimal to tax pure rents at the highest possible rates. Pure rents are not the compensation for economic efforts and are therefore an ideal tax base as there are no distortions involved in taxing rents. Hence, the government can lower distortionary taxes elsewhere. Using the Chamley-Judd setting, Correia

\footnotetext{
${ }^{10}$ Judd (1999) demonstrates that when there are non-deductible costs of investment in human capital, a consumption tax (i.e., a zero capital tax) is no longer neutral with respect to investments in human capital as long as these costs cannot be deducted against the rate at which future returns are taxed.
} 
(1996) demonstrates that optimal capital taxes are positive when a part of capital income consists of rent income arising from a fixed factor. Therefore, it is socially desirable to tax immobile capital, such as houses. The value of the house mainly reflects the scarcity of the land on which the house has been built (Van Ewijk et. al., 2007). The same is true for dividend incomes and capital gains on shares from firms that benefit from locationspecific advantages, infrastructure, brand name, monopoly power, or increasing returns to scale. For the same reason it would also optimal to tax non-intentional bequests. Capital incomes consist at least for some part of rent income, for which no economic sacrifice has been made. Hence, it is efficient to tax capital income to capture some of the rent.

\section{Capital-income taxes are optimal when capital markets fail}

Many households face binding liquidity constraints (Attanasio and Weber, 2010). Capital markets may fail to provide loans due to asymmetric information between financiers and borrowers, which results in moral hazard and adverse selection. Moreover, labor earnings cannot be used as collateral in financial contracts, since modern states have abolished slavery. Ideally, borrowing constraints should be alleviated by providing borrowing facilities. However, as long as that is not the case, capital-income taxes help to correct this market failure (Aiyagari, 1995). Intuitively, borrowing constraints result in inefficiently high levels of saving and, thereby, overaccumulation of capital. Formulated differently, with binding borrowing constraints the relative price of future consumption in terms of current consumption is lower than the marginal rate of transformation between future and current consumption. Taxing capital incomes reduces the incentives to save of those who are not borrowing constrained. By redistributing the proceeds of the capital-income tax the credit constraints for those who cannot borrow are alleviated. Capital income taxes thus help to complete the missing market for borrowing by transferring resources from those who can to those who cannot borrow. Aiyagari (1994) simulates optimal capital-income taxes and finds that the optimal capital-income tax is around 45 percent in the simulation using the most realistic wage elasticity of labor supply (with a value of one this is still unrealistically high). Hubbard and Judd (1986) also find that capital income should be taxed in the presence of liquidity constraints using a realistically calibrated model for the US.

\section{Capital-income taxes are optimal when insurance markets fail}

Capital-income taxes are desirable when individuals cannot insure the risks in their labor earnings. This is true even if the government directly insures income risks through the labor-income tax and social insurance arrangements (Diamond and Mirrlees, 1978, 1986; Nishiyama and Smetters, 1995; Golosov et al., 2003; Jacobs and Schindler, 2012). Due to moral hazard problems in social insurance, it is never optimal to perfectly insure individuals against all labor income risk. The government trades off the gains from social insurance against the disincentives to supply labor. By taxing capital income, however, 
the government can indirectly boost labor supply by changing the labor supply profile over the life cycle. In particular, by taxing capital income labor supply at later ages increases, whereas labor supply at earlier ages decreases. This works through both intertemporal substitution in leisure (future leisure becomes relatively more expensive) and intertemporal wealth effects (lower saving boosts future labor supply). If labor supply increases on average, capital-income taxes are useful to counter the labor-tax distortions. This is very similar to the complementarity argument discussed above. Indeed, empirical evidence suggests that labor supply falls when capital incomes increase (Pirttilä and Suoniemi, 2010). In addition, wealth is a state variable that absorbs the earnings risk during earlier phases of the life cycle. Hence, capital taxes may complement the labor-income tax to insure labor income risks. This is relevant when the government can only use linear labor-income taxes (see Jacobs and Schindler, 2012).

Banks and Diamond (2010) refer to many empirical studies showing that earnings risk over the life cycle is very substantial. Nishiyama and Smetters (1995) simulate a detailed applied stochastic general-equilibrium model of the US. They find that introducing earnings risk radically changes optimal tax policy. In particular, in the absence of earnings risk they demonstrate that replacing a comprehensive income tax (equal rates on capital and labor incomes) with a pure expenditure tax delivers a huge life-time welfare gain of $\$ 154.000$ for each household. However, when labor-market risk is not insurable, the same tax reform lowers expected life-time welfare with $\$ 86.000$ per household. Consequently, by ignoring non-insurable labor market risks one can substantially bias policy conclusions.

\section{Capital-income taxes tax labor income in disguise}

Capital income might be taxed as well for redistributive reasons. However, the arguments to tax capital incomes for redistributional reasons are much more subtle than popular policy discussions often suggest. Indeed, one needs to ask the question whether the capital-income tax could supplement the labor-income tax if doing so can redistribute more income than is already possible with the labor-income tax alone.

Capital incomes could be labor income in disguise. Some individuals generate substantial higher returns to savings, stock market investments, entrepreneurial efforts, and other investments. Then, capital incomes are to some extent a return to labor supply, work effort, human capital, or investment ability (Cnossen and Bovenberg, 1999; Banks and Diamond, 2010). Taxing capital income is then desirable to redistribute resources from individuals with a high earning ability to individuals with a low earning ability. Gordon and Kopczuk (2010) demonstrate that both capital incomes and owner-occupied housing are strongly increasing in the wage per hour worked. They conclude that capital incomes and houses should therefore be taxed for redistributive reasons so as to complement the non-linear income tax with redistribution. It is unclear, however, whether high capital incomes are the result of higher earning ability or differences in preferences to save or to own a house. Individuals with higher ability might be more patient or have a stronger 
preference to own a house. However, taxing capital income is then also optimal (see also below when heterogeneous preferences are discussed).

\section{Capital-income taxes complement flat labor-income income taxes}

Empirical research demonstrates that inequality increases rapidly over the life cycle (Attanasio and Weber, 2010), especially, because consumption becomes more unequally distributed as individuals age. Taxing capital incomes may then be desirable to reduce inequality and to improve the redistributive powers of the tax system. The reason is that taxing consumption at later dates provides larger distributional benefits than taxing consumption at earlier dates in the life-cycle. However, this argument is valid only if the government is constrained in employing a fully non-linear labor-income tax, such as a flat tax, and if the government does not directly tax (non-intended) bequests. In that case, capital-income taxes reduce inequality over the life-cycle and reduce differences in initial wealth holdings. With a non-linear labor-income tax, the government cannot redistribute more income by also levying a capital-income tax, but it does distort saving behavior. Hence, a tax on savings is not beneficial to reduce inequality. Still required is a tax on bequests so as to reduce initial wealth differences.

\section{Capital-income taxes are optimal when high-ability individuals have a stronger preference to save}

If individuals with a higher earning ability also have a stronger preference to save, then it is optimal to tax savings for redistributive reasons (see also Mirrlees, 1976; Saez, 2002b; Diamond and Spinnewijn, 2011). Intuitively, conditional on observing labor income, saving patterns then provide additional information as to who has a higher earnings ability. Consequently, taxing savings helps to redistribute income at the lowest efficiency costs. Note that rising inequality over the life-cycle, as discussed in the previous point, might be explained by differences in preferences to allocate consumption over the life-cycle. Banks and Diamond (2010) discuss many studies presenting evidence that earnings ability and the willingness to save are strongly correlated. Hence, taxing savings is welfare optimal.

\section{Summary taxation of capital income}

In contrast to the Mirrlees Review (2011), it needs to be concluded that some taxation of the normal return to capital is desirable, in accordance with Banks and Diamond (2010). A dual-income tax, as is present in many Scandinavian countries, appears to be most desirable from a welfare-economic point of view, see also Cnossen and Bovenberg (1999). From a welfare-economic point of view, one should not expect that two tax bases should be taxed at the same rate except in knife-edge cases.

One such knife-edge case is relevant for the taxation of capital incomes. When assets can be perfectly substituted in household portfolios, it is impossible to levy different rates on 
different types of capital income. Clearly, there are also practical limits to differentiate tax rates on different tax bases depending on how easily taxes can be avoided via tax planning. Therefore, most forms of capital income, such as interest income, dividends, capital gains, imputed returns on housing, and accrual of pension wealth, should probably be taxed symmetrically under one uniform tax regime for capital incomes. However, additional measures could be taken for housing wealth and bequests to tax rents and initial wealth. If capital incomes are taxed, then the costs of generating these capital incomes should be deductible. This should, for example, imply that costs of mortgages are deductible, but also the interest payments on consumption or study loans.

How high should the optimal tax rate on capital income be? This question is easily posed, but a definitive answer cannot be given because research is lacking precisely quantifying all arguments raised above in realistic applied models. Like the optimal labor-income tax, the optimal capital-income tax also depends on political preference for income redistribution. In any case, it seems reasonable to expect that the optimal tax rates on capital and labor income should move up and down together (Banks and Diamond, 2010).

\section{The Dutch wealth tax}

The Netherlands abolished the capital-income tax on the personal level in the large tax reform of 2001. By then, interest incomes and dividends were taxed, capital gains remained untaxed. In 2001, the wealth tax - with a low rate above a very large exemption - was also abolished. In the current system, all assets (apart from housing and pension wealth) are subject to a wealth tax of 1.2 percent, above an exemption of about 20,000 euro per person. This wealth tax is based on the fiction that all assets earn a nominal return of 4 percent, and the tax rate on this nominal return equals 30 percent. Euphemistically, tax authorities call this wealth tax a 'presumptive capital-income tax'. The tax reform did nothing to change the taxation of pensions and housing and both remained heavily subsidized. Realized capital income earned by large shareholders in closely-held companies is taxed separately at a rate of 25 percent, before and after the reform.

This tax reform made little economic sense. The wealth tax does not tax anything above the normal, risk-free return, such as the risk-premium, compensation for investment ability, returns for entrepreneurship, informational advantages, above-normal returns due to pure profits, and so on. In doing so, the Netherlands has moved in exactly the opposite direction as the recommendations of the Mirrlees Review (2011): tax the normal return on capital, exempt the above-normal return to capital. Clearly, this results in efficiency losses, since taxing abovenormal returns is less distortionary than taxing the normal return. Moreover, it is easily seen that exempting the above-normal return is highly inequitable. The average tax for someone making a return of only 2 percent on a savings deposit is 60 percent, whereas for someone investing in the stock market, and earning a return of 10 percent, the effective tax rate is only 12 percent. ${ }^{a}$ Hence, average tax rates on capital incomes have become steeply regressive. Similarly, the current capital-tax system provides less social insurance, since the government does not share in the risk-premium on risky investments. 
The introduction of the wealth tax was politically defended by referring to the so-called 'robustness' of its tax revenues. This argument has no welfare-economic foundation. Robust revenue is the mirror image of less social insurance. The government does not share anymore in good and bad luck of asset holders as they have to pay the wealth tax irrespective of whether they make a positive or a negative return on their assets. From a macro-economic point of view, this tax policy is pro-cyclical; average taxes good times are lower, and in bad times higher, which is due to the regressive nature of the tax. Robust tax revenues can be nice for the Minister of Finance, but this also gives a loss in social welfare.

The wealth tax in the Netherlands should preferably be replaced by a true capital-income tax, which taxes capital incomes, not wealth holdings (Cnossen and Bovenberg, 1999). Capital losses can be off-set for a number of years against realized capital gains. To avoid lock-in effects, realized capital gains should be taxed at death or migration. Delaying the realization of profits should be avoided by charging interest on delayed capital realizations. Lock-in effects can be overcome completely by taxing accrual of wealth. However, this can only be done for assets which are traded in markets and have a clear valuation, such as stocks.

${ }^{a}$ This example presumes a zero tax exemption for illustrative purposes.

If the government taxes all sources of wealth, then levying a wealth tax is redundant. Sometimes it is argued that wealth should be taxed for non-welfarist reasons, because wealth yields power, status and security (see for example Cnossen and Bovenberg, 1999). These are rather ad hoc motives that cannot be defended easily from a welfare-economics point of view (see also Boadway et al., 2010).

To conclude, the optimal tax literature does not provide any evidence that capital incomes should be taxed in the same way as labor incomes. Indeed, the Schanz-Haig-Simons ability-to-pay concept appears to be completely at odds with optimal-tax principles. A pure consumption/expenditure tax cannot be defended either from welfare economic principles. Indeed, a pure consumption/expenditure tax is optimal only when all the following, very strict conditions are met:

- Individuals act as if they have an infinite time horizon, or they form a dynasty of perfectly altruistically generations that are linked through an unbroken chain of bequests;

- When individuals have finite lives (or are not perfectly linked across generations) the marginal willingness to save should be independent of labor supply or earnings ability (weakly separable and identical preferences), and the government should be able to levy a perfectly non-linear income tax on labor earnings;

- All costs of all conceivable investments whose returns are taxed under the laborincome tax should be made tax deductible at the rate of the labor-income tax. Hence, investments in education, training, entrepreneurship, etc. need to be verifiable and deductible; 
- All capital incomes can be perfectly separated from labor incomes, especially at the firm level (small enterprises and closely-held firms with a large owner-shareholder);

- Capital markets should work frictionless, hence individuals should be able to borrow against all possible assets (including human capital, housing and pension wealth);

- Insurance markets are perfect and complete. Hence, 100 percent private insurance of all possible labor and capital income risks is feasible;

- Capital incomes should not contain any pure rents due to monopoly profits, location rents, fixed factors (land), and so on;

- Returns on all sources of capital incomes should be identical for all individuals and cannot be the reward for earning ability, entrepreneurship, human capital or investment talent;

- There should be no correlation at all between earnings ability and the willingness to save in ordinary saving, housing or pensions.

Clearly, these conditions are not met in reality. Therefore, it still is somewhat of a mystery why the Mirrlees Review (2011) recommended to exempt the normal return to saving, thereby overriding the recommendation of Diamond and Banks (2010) in the same Mirrlees Review to have some taxation of the normal return on saving.

\section{Taxation of pensions}

In many countries premiums for pensions are tax deductible, accrual of pension wealth remains untaxed, and pension benefits are taxed. Moreover, pensioners generally pay lower social-security contributions, sometimes even zero (OECD, 2011c). This tax treatment of pension income implies that a large subsidy on pension saving is provided. This subsidy consists of two parts. First, the tax rates at which pension contributions are deducted is typically larger than the tax rate at which pension benefits are taxed if tax systems are progressive, labor incomes when retired fall in lower tax brackets, and elderly generally face lower tax rates. Second, ordinary savings are generally subject to the capital-income tax, whereas accrual of pension wealth typically remains untaxed. The distributional impact of these subsidies on saving is generally regressive, since high-income earners save more for their pensions.

Behavioral economics provides sufficient evidence that individuals are short-sighted and have difficulties with pension planning. This could justify requirements to save for old age. However, from a welfare-economic point of view it is unclear why the government should, in addition, subsidize the accrual of pension wealth through generous tax facilities. If it is so desired that individuals accumulate more pension wealth, then the government could easily raise the minimum level of required pension savings, without a budgetary cost. 
In addition, if capital income should optimally be taxed at a positive rate, see previous section, then it is not clear why capital income generated in pension funds should remain tax exempt. Moreover, to avoid arbitrage, both intertemporally and between different assets, increases in pension wealth should receive the same tax treatment as ordinary savings. Doing so would restore symmetry in the tax treatment of pensions and other types of capital income. Even when taxing the investment returns in pension funds, one can keep a deduction for pension contributions in the income tax, but it would then be desirable to apply the same tax rate on pension benefits as the rate at which pension contributions have been deducted.

Removing the tax-favored status of pension savings potentially yields a lot of tax revenue, which can be used to cut tax rates on labor income, so as to reduce the distortions associated with labor-income taxes. Naturally, there could also be distortions in saving decisions by taxing accrual of pension wealth. However, the previous section demonstrated that some taxation of capital income is optimal. Voluntary pension savings will certainly be affected, but this typically applies to savings by self-employed individuals, wealthy individuals that have large non-institutional savings and employees with a pension gap, whose accumulated pension entitlements are low. However, distortions in pension saving will be relatively limited when individuals have little control over these savings if these are determined institutionally.

\section{Taxation of housing}

Many countries have an extremely lenient tax treatment of owner-occupied housing. Examples include the Netherlands, Norway, Sweden, Denmark, Belgium and the US (OECD, 2011b). Interest costs of mortgages can be deductible from the income tax and taxation of imputed rent is low or even absent (Andrews et al., 2011). Generally, housing is subject to property taxes (at the local level). The budgetary cost of this favorable tax treatment can be large, especially when households have built up large leverage (large mortgage debt relative to housing equity).

Why would the government subsidize owner occupied housing to such a large extent? Very often it is claimed that home-ownership generates positive externalities as house owners take more care of their house and their neighborhood. Indeed, a robust correlation between home-ownership and quality of the neighborhood is found in the literature. However, correlation does not imply causation. Most studies do not control for selection biases and endogeneity issues, hence they should be interpreted with caution (Van Ewijk et al., 2007). Indeed, home owners have typically a higher income and are better educated than tenants. Arguably, most of these home owners would take better care of their environment and house as well when they still rented a house.

In addition, subsidies on owner-occupied housing are typically very regressive, since home-ownership correlates heavily with income. Expenditures on housing are tightly as- 
sociated with individual earnings ability (Gordon and Kopczuk, 2010). Static income measures give a very biased view on the real regressive incidence of housing subsidies due to life-cycle effects and general equilibrium effects in housing markets. Life-cycle effects severely distort the static incidence of housing subsidies, since younger households have low earnings and high mortgages. As a result, they typically benefit most from housing subsidies in terms of their income. Older households have generally higher earnings and lower mortgage debt, so they seem to benefit less. Calculating the life-time benefits of housing subsidies in terms of life-time incomes would remove this bias.

Moreover, housing supply is typically not very elastic, depending on government regulations. Housing supply appears to be least elastic in continental Europe (supply elasticities below 0.5), but more elastic in Nordic and Anglo-Saxon countries (Caldera Sánchez and Johansson, 2011). If housing supply is inelastic, the incidence of a subsidy (or a tax) always falls on the least elastic side of the market. The main part of the housing subsidies will then simply be capitalized in higher housing prices. This implies that mainly home sellers benefit from housing subsidies, i.e., the older generations, and not the home buyers, i.e., the younger generations. This also biases the static incidence measures. Whatever the reason is that the government would like to promote home-ownership through tax-facilities on housing, this policy will hardly be effective when the elasticity of housing supply is very low. Indeed, such a policy then mainly promotes high housing prices, not more widespread home ownership.

If interest costs are deductible, and imputed rent is very low (or zero), households receive strong tax incentives to finance their houses as much as possible with debt so as to benefit from this tax shield. The global financial crisis has demonstrated that high leverage can be very risky. By raising leverage of households, tax incentives to promote debt financing strengthen 'boom-and-bust' cycles in the economy. In addition, tax incentives for debt financing raise the exposure of the banking sector to risks in the housing market, thereby further exacerbating the 'boom-and-bust' cycle. In the Netherlands, Sweden, the UK, the US, Australia, Ireland and Denmark mortgage debt hovers between $80-100+$ percent of gdp in 2009 (IMF, 2011).

Low housing-supply elasticities also imply that the welfare losses of stimulating homeownership in the housing market (i.e. overconsumption of housing) are limited. Indeed, the main welfare losses can be found in the labor market. The tax burden on labor income needs to increase substantially to finance the subsidies on owner-occupied housing. Marginal taxes on labor income can therefore decline across the board if the tax-subsidies on owner-occupied housing would be abolished.

From an economic perspective, mortgage rent deductions and low (or no) taxation of imputed rent makes hardly any economic sense. In principle, housing assets should be treated symmetrically with other assets. Hence, both costs and returns on housing should be taxed under the capital-income tax. Mortgage rent can be deducted against the rate of the capital-income tax, whereas imputed rent should be taxed at that same rate. Imputed rent should be based on a presumptive rate of return on housing investments. This rate of 
return does not only consist of the risk-free interest rate, but also consists of a risk/liquidity premium, corrections for depreciation, costs of insurance and maintenance and transaction costs (Poterba, 1984). Accordingly, an imputed rent on housing of about 4-6 percent of the property value seems reasonable. ${ }^{11}$

Since property is an illiquid asset, the government may introduce a borrowing facility for home owners that have fully paid off their mortgage loan, have no labor earnings, but still do have to pay the tax on imputed rent. If capital markets do not provide consumption loans using the house as collateral, home owners need to sell their property so as to pay the tax on imputed rent. This can be avoided by giving tax payers the possibility to defer these tax payments for a number of years until the house is sold, the tax payer dies or migrates. At the moment the house is sold, there is no liquidity problem anymore, and government can collect the tax claim, including interest.

When imputed returns on owner-occupied housing are raised to the same rate as the nominal return on housing, debt and equity invested in owner-occupied housing are taxed symmetrically. Hence, the incentives for excessive leverage vanish.

In addition, capital gains made on selling owner-occupied houses should be taxed as well, just like ordinary capital gains on stocks, for example. Capital gains $(G)$ are equal to the selling price at date $t\left(P_{t}\right)$ minus the acquisition price at date $0\left(P_{0}\right)$, corrected for the (compounded) imputed annual return of 4-6 percent $(r): G=P_{t}-(1+r)^{t} P_{0}$. Capital losses could be be offset against realized capital gains for a number of years.

Housing prices reflect scarcity rents of the land on which houses are constructed and the attractiveness of the location of the house. This is especially true when housing supply is not very elastic. According to optimal-tax principles, these rents should be taxed, preferably at high rates. It is plainly baffling for an economist to see that countries like the US, the Netherlands and Norway subsidize home owners rather tax them. Indeed, it may even be desirable to tax housing assets at a higher rate than other assets. One could do so by increasing imputed rent. An alternative is local property taxes, since housing prices also reflect the value of public good provision at the local level. Hence, property taxes can serve as an indirect benefit tax for local public goods.

Some may argue that owner-occupied housing should be seen as a consumption good, not as an asset. In this view, home owners cannot deduct mortgage-rent payments from their income tax, and they do not need to pay tax over imputed rent either. This is not a desirable policy option, since houses are (besides pension wealth) one of the most important assets of households. By not treating housing as an asset, individuals will get very strong incentives to accumulate wealth through untaxed real-estate investments. Moreover, capital

\footnotetext{
${ }^{11}$ Of course, taxing imputed rent entails administrative costs to assess property values for tax purposes. In order to adequately reflect property values the assessments need to be made frequently and with substantial differentiation between properties. Some countries do tax imputed rent, e.g. in Iceland, Luxembourg, the Netherlands, Slovenia and Switzerland, see Andrews et al. (2011). Consequently, taxing imputed rent is possible in practice. In the Netherlands this is done on the basis of property values in housing transaction registers.
} 
gains on houses would remain out of reach of the tax authorities. And, if housing supply is very inelastic, the government does not tax a tax base consisting mainly of rents, thereby shifting the tax burden to other, much more distortionary tax bases.

Equalizing tax treatment of owner-occupied housing to that of ordinary savings would allow the government to reduce labor-income taxes. Moreover, overconsumption of housing would be avoided, thereby reducing distortions in the housing market. This is a smaller distortion the more inelastic is housing supply. However, income effects are very complex when housing supply is inelastic. Indeed, removal of the subsidies on the demand for houses will inevitably result in house-price declines. These general-equilibrium effects are the most important political obstacle towards a more sensible tax treatment of housing. Reforming the tax treatment of owner-occupied housing while compensating home-owners for price declines will erode the potential welfare gains. Indeed, when home owners would all be perfectly compensated for a price decline, then no revenue will be left to reduce income taxes. In that case, the policy reform is useless.

A policy change is more likely to be successful when tax rates are lowered for those groups that are hurt by the removal of the housing subsidy, i.e. the higher income groups. Lowering income taxes also helps to boost demand for housing to that the decline in housing prices is dampened. Given that housing markets are forward looking, a slow phase-in of policy measures need not be successful to avoid immediate house-price declines. Since buying a house is a long-term investment, future policy changes directly translate into changes in current housing demand. A well-designed transition regime should preferably protect home-owners with low or negative equity invested in their house. Typically, these will be young households that have just bought a house with a large mortgage loan. Focusing compensation on these groups helps to limit resources spent on compensation. Moreover, a reform will then act as an indirect capital levy on those households that have experienced very large capital gains on their house, and that do not run into financing issues, because they have paid off their mortgage loans.

Generic transition measures are not suitable when removing housing subsidies. For example, introducing a general exemption of the capital-income tax for housing (up to some maximum) is not desirable, since not only the households with low/negative equity will benefit, but every household. Since the welfare gain of the reform is primarily driven by the revenue it generates, transition measures that soak up large parts of the revenue yield much lower welfare gains. Similarly, a gradual increase in imputed rent moves the tax system into the right direction, but it is also generic and may therefore be unsuited measure to address transition issues.

As a final remark, in some countries there are stamp duties on the value of housing transactions. These are very distortionary taxes, since they reduce both labor and housing mobility a lot (Van Ewijk et al., 2007; OECD, 2011b). There is no clear economic rationale for such transaction taxes, hence it would be desirable to abolish them. 


\section{Indirect taxation}

If the government can use direct instruments for income distribution, i.e., income taxes, tax credits and transfers, should it use indirect instruments as well? In optimal-tax theory, a lot of attention has been paid to the division of direct vs. indirect taxes. The main insight is that indirect instruments should be used for three potential reasons.

First, taxing or subsidizing commodities is useful if doing so raises labor supply. Intuitively, the government then alleviates the distortions of the income tax on labor supply. Hence, goods that are relatively more complementary to leisure should be taxed more. Examples could be alcohol, travel, and tourism. Goods that are relatively more complementary to work should be taxed less. Examples could be work-related cost of travel, child-care facilities, or education. However, this comes at the cost of distorting commodity demands, since households demand relative more goods on which lower taxes are levied (Atkinson and Stiglitz, 1976; Mirrlees, 1976). These welfare losses in goods markets need to be traded off against the welfare gains in labor markets. When the willingness to pay for commodities does not vary with labor effort, preferences of households are weakly separable between consumption and leisure. In that case, and the famous Atkinson-Stiglitz (1976) theorem applies and indirect instruments are redundant.

There is surprisingly little empirical evidence estimating the degree of complementarity of various commodities with work effort. Available research does not provide particularly strong evidence in favor of weakly separable preferences, see also Crawford et. al (2010) and Pirttilä and Suoniemi (2010). Crawford et al. (2010) find that for the UK food, energy, tobacco and public transport are complementary to leisure, whereas restaurant dinners, alcohol (!), and fuels are complementary to work. Pirttilä and Suoniemi (2010) show that in Finland capital income and expenditures on housing are complementary to leisure, whereas child-care facilities are complementary to labor. Most expenditure categories in both studies, however, show no significant association with labor supply. Given the tremendous importance of the Atkinson-Stiglitz theorem in the optimal-tax literature it is rather surprising and disappointing that not more direct evidence is available on its empirical validity.

However, the scarce empirical research does not point to strong complementarities of commodity demands with labor for many goods. Some obvious exceptions are discussed above. As a general rule, it would probably be best to have no commodity tax differentiation and that in particular, well-reasoned cases, one can deviate from this rule. From a practical point of view, implementation of differentiation in indirect instruments, notably the value added tax (VAT), is a complex task, especially when goods cross nation borders (Cnossen, 2010). Crawford et al. (2010) argue that the potential welfare gains of VAT-rate differentiation are limited in scope and that these need to be traded off against the ad-

ministrative and compliance costs. They suggest that VAT-rate differentiation yields too small welfare gains to compensate these costs and is therefore not desirable.

Second, indirect instruments might be useful as a distributional device. The question 
is whether indirect instruments should be used when the government can also redistribute income through the income tax. Politicians often argue in favor of indirect instruments for equity reasons. In many countries large amounts of resources are redistributed through subsidies on commodities, for example through low VAT-rates, income-dependent tax credits, subsidies or provision in kind. The equity argument in favor of indirect taxation only is valid if $i$ ) the government uses an informationally inefficient income tax (such as the flat tax) for income redistribution or if ii) individuals differ not only in their ability, but also in their preferences for certain goods.

Under a fully non-linear income tax, using indirect instruments for redistribution does not generate distributional gains - over and above the gains that can be achieved with the income tax - but do distort commodity demands. Intuitively, all heterogeneity is in earnings ability. Conditional on observing (and taxing) earnings, it is not useful to levy taxes on other tax bases if these tax bases provide no signal as to who has a low or a high ability. Hence, the trade-off between equity and efficiency cannot be improved and indirect taxes should not be used for redistribution.

However, when the government can only employ linear income taxes, much stricter conditions are needed to find no role for indirect instruments (Sandmo, 1974; Atkinson and Stiglitz, 1976; Deaton, 1979). In particular, the marginal willingness to pay for commodities should not vary with labor effort, just as with non-linear instruments. Indeed, if this is the case then all commodities are equally complementary to leisure and uniform commodity taxes are optimal. Moreover, preferences of households need to be such that commodity demands feature linear Engel curves (in jargon: the utility function should be weakly separable between labor and commodities and it should be homothetic in all commodities). In that case, expenditures on all commodities are linear in labor earnings. Hence, taxes on commodities have the same distributional impact as taxes on earnings. Consequently, indirect taxes and income taxes can achieve the same redistribution, but indirect taxes, in addition, distort commodity demands. These can be avoided by not using indirect instruments for redistribution. Empirically, there appears to be no evidence supporting linear Engel curves, see Crawford et al. (2010) and Pirttilä and Suoniemi (2010). Hence, an important disadvantage of a flat tax is that it becomes optimal to employ all kinds of indirect instruments for redistribution. This can be avoided by using non-linear income taxes, see also the discussion on the flat tax.

Moreover, if individuals do not only differ in their earning ability, but also in terms of their willingness to pay for certain commodities (i.e. preference heterogeneity), then taxing these commodities helps to redistribute resources, even under non-linear income taxation. Intuitively, when the preference to consume certain commodities correlates with earnings ability, conditional on observing earnings, commodity demands provide useful additional information on who has a high or a low ability and, therefore, should be used for redistribution (Mirrlees, 1976; Saez, 2002b). For example, Gordon and Kopczuk (2010) present empirical evidence that home-ownership (and capital income) strongly correlates with earnings ability. 
There is no clear evidence supporting low VAT-rates on necessities and high VATrates on luxuries. These categories of goods are generally too 'broad' to have substantial distributional benefits. Crawford et al. (2010) also show for the UK that a flattening of VAT-rates with the appropriate adjustments in the non-linear income tax hardly has distributional consequences. This implies that the distributional objectives can be achieved with an income tax, and no distinction between luxuries and necessities need to be made.

In many countries, many goods are exempted from value-added taxes or are taxed at a zero rate, for example in education, agriculture, real estate, public services, arts, books, child care or the financial sector. These exemptions do not have a clear welfareeconomic rationale. Exemptions distort production decisions (violation of the Diamond and Mirrlees (1971a) production efficiency theorem), create unlevel playing fields, obstruct fair competition and distort the terms of trade. Hence, these exemptions should be abolished, see also Crawford et al. (2010) and Cnossen (2010).

Value-added taxes are not the only indirect instruments. Indeed, most countries also provide indirect subsidies on, for example, housing costs and health care. From an economic point of view, these policies only make sense if there is a clear relation of health and housing consumption with labor market behavior. Pirttilä and Suoniemi (2010) show that expenditures on housing are complementary to leisure. If anything, this suggests that housing should be taxed rather than subsidized. ${ }^{12}$ Highly subsidized housing or health care promotes overconsumption of housing and health care. Therefore, many income support programs directed towards the poor may be integrated in the income tax system. In principle, the same income redistribution can be organized while avoiding overconsumption of particular commodities.

Although there are no clear welfare-economic motives why goods such as health care and housing are subsidized, there might well be non-welfarist reasons for doing so. For example, in Sens' (1985) capability approach, maximizing social welfare is not seen as the proper objective for the government. Indeed, the government should be concerned with (the distribution of) capabilities. Subsidizing health care and housing can be seen as capability enriching, hence can be defended on that ground. Similarly, from behavioral economics we know that individuals may be subject to all kinds of self-control issues. Thus, it may be desirable to provide subsidies in kind rather than cash transfers (Kanbur et al., 2006; Currie and Gahvari, 2008).

Another issue often discussed in the policy arena is whether there should be a lower tax rate on goods in labor intensive sectors (e.g., a lower VAT-rate or a lower payroll tax rate). Applying the principles of optimal taxation, this is only beneficial if the consumption of

\footnotetext{
${ }^{12}$ One could make the argument that expenditures on health are some form of human capital investments. Hence, there would be a case to subsidize health expenditures, since healthier individuals work more, retire later and are less dependent on social benefits for illness or disability. On the other hand, one may suspect that an ability bias in health is present. High-ability and therefore high-income groups benefit more from the same health expenditure in terms of improved labor-market prospects. Consequently, it is not clear that health should be subsidized or publicly provided (see also Jacobs and Bovenberg, 2011)
} 
goods that are produced in labor intensive sectors are more complementary to work than goods produced in other sectors. Alternatively, such a low rate can discourage blackmarket activities by promoting employment in the formal sectors (Sørensen, 1997). It is a priori unclear whether the broad category of labor-intensive sectors produce goods that are indeed more complementary to work than goods produced in labor-extensive sectors. It would apply, for example, to cleaners, restaurants, and child-care services, which are goods that are close substitutes for household production. However, other goods produced in labor-intensive sectors may be more complementary to leisure, such as maintenance for gardens and housing, bars and shops. Insofar as one wishes to lower the marginal tax burden at the lower end of the earnings distribution, so as to boost low-skilled employment, it is probably better to do this directly through generic reductions in the income tax rate, for example with an EITC. Taxing labor-intensive sectors at a lower rate induces production inefficiencies as too much labor will be allocated towards these sectors and consumption patterns will be distorted. In addition, one may wish to directly subsidize substitutes for household production, rather than providing general tax relief for labor-intensive services.

\section{Corrective environmental taxation}

Apart from income redistribution, the government also needs to correct externalities. Ever since Pigou (1920) economists have been forceful advocates to use tax instruments in order to internalize externalities. Naturally, taxes can be a useful device to do this, although also other instruments could be used that achieve the same goals, such as regulation, subsidies, auctions, and so on.

The deterioration of the environment caused by global warming is a threat to the survival of the planet. Stern (2007) therefore speaks of the 'the greatest and widest-ranging market failure ever seen'. Tax instruments can potentially be employed to internalize externalities associated with CO2-emissions, which cause global warming. This implies that the government is right to levy taxes on energy (gas and electricity), fuels (petrol and gasoline), etc.

Environmental taxes should be introduced mainly for environmental reasons. The optimal Pigouvian tax exactly internalizes the external damage of polluting consumption in market prices. The optimal Pigouvian tax only depends on the size of the marginal external damage and is independent from the demand elasticity (as sometimes suggested). A lower consumption of a polluting good generally induces substitution towards non-polluting alternatives. Therefore, positive externalities in the development of alternative and sustainable energy sources can also be interpreted as negative externalities in the use of ordinary energy. Calculating the externalities is, however, a daunting task, see also Fullerton et al. (2010).

Many politicians and fellow economists claim that environmental taxes should be employed to raise revenue or to lower taxes on labor so as to shift the tax burden towards pol- 
luting consumption goods ('greening of the tax system'). This claim is generally incorrect, since it refers to the most efficient ways to raise tax revenue. From a non-environmental point of view, indirect taxes on particular commodities should not be used to raise revenue as long as the demand for these commodities does not relate to labor-market behavior. Indeed, one can immediately invoke the Atkinson-Stiglitz theorem to argue that environmental taxes are not the most efficient way to raise revenue or to redistribute income. Intuitively, environmental taxes distort labor supply just as much as an equal-revenue labor tax would do. In addition, environmental taxes also distort the composition of consumption. These distortions are desirable from an environmental point of view, but not from a non-environmental point of view. Indeed, environmental taxes reduce the real wage more than an equal-revenue income tax would do and thereby exacerbate the tax distortions on labor supply. From a non-environmental point of view it is therefore not optimal to raise revenue through environmental taxes if the government can also levy direct taxes (Sandmo, 1975; Bovenberg and De Mooij, 1994). Therefore, 'greening of the tax system' cannot be a correct policy goal.

Similarly, maximizing tax revenue from environmental and pollution taxes cannot be a goal of environmental tax policy. The level of environmental taxes is primarily determined by the size of the environmental damages. Only in knife-edge cases Pigouvian environmental taxes coincide with the revenue-maximizing tax rates. Indeed, the optimal environmental taxes could both be below and above revenue-maximizing rates.

If for environmental reasons (not revenue reasons) a positive environmental tax is levied, labor-market distortions typically increase if there are pre-existing labor-income taxes. However, this should not lead to the conclusion from Sandmo (1975) and Bovenberg and De Mooij (1994) that optimal environmental taxes should be set below the Pigouvian rate. Jacobs and De Mooij (2011) demonstrate that larger distortions in the labor market are compensated by distributional benefits of labor taxes, which are ignored by Sandmo (1975) and Bovenberg and De Mooij (1994). Under suitable separability assumptions, the optimal environmental tax in second-best will still be identical to the first-best Pigouvian tax.

When designing environmental taxes, the government needs to take into account the second-best interactions of consumption of polluting goods and environmental quality with labor supply (Jacobs and De Mooij, 2011). If consumption of polluting goods boosts (reduces) labor supply, environmental taxes exacerbate (alleviate) the distortions of the income tax on labor supply and should therefore be set at a lower (higher) rate than the Pigouvian level. Similarly, if a better environmental quality boosts (reduces) labor supply, environmental taxes should be set lower (higher) than the Pigouvian level. However, not much is known empirically about the complementarity of polluting goods and environmental quality with respect to leisure compared to non-polluting goods. Fossil fuels appear to be complementary to labor supply in the UK, see Crawford et al. (2010). Crawford et al. (2010) also demonstrate that in the UK energy use is more complementary to leisure. Nevertheless, it is hard to generalize these findings to other countries. Based on the principle of insufficient reason it therefore seems best to set environmental taxes at the Pigouvian 
rate.

As long as the government can employ a non-linear income tax, environmental tax policy is exclusively determined by efficiency considerations (externalities and interactions with labor supply). Hence, the design of environmental policy can disregard distributional issues. Distributional consequences of environmental taxes can be addressed by appropriate adjustments in the non-linear income tax. However, if the government is constrained in using a non-linear tax, for example because there is a flat tax, then the distributional effects of environmental determine also environmental policy. In particular, environmental taxes should be set lower than the Pigouvian rate when environmental policies have adverse consequences for the income distribution (Jacobs and De Mooij, 2011).

The main determinant of environmental taxes should be the marginal external damage. Tol (2008) presents a meta-analysis of studies estimating the social cost of carbon. On average these studies present an estimate of $\$ 24-35$ per tonne CO2-emissions. Stern estimates that the social cost of carbon can be as high as $\$ 85$ per tonne CO2-emissions. These estimates are on the very high end and belong to the highest in the literature. Nordhaus (2007) criticizes Stern's estimates because the calculations cannot be reproduced, insufficient weight is given to counter arguments, and discount rates are set at too low values.

Whatever the outcome of this scientific debate, by taking a baseline estimate for the social cost of carbon, one can in principle calculate the implied Pigouvian taxes on energy and fuels and compare those to the current level of excises. An international comparison of effective taxes on energy or fuel per tonne of $\mathrm{CO} 2$ emissions is difficult to make due to the large heterogeneity in systems of energy and fuel taxation (OECD, 2010). We will take the current Dutch case as an illustrative example. Excises on households' energy use are already way above Stern's value for the social cost of carbon: gas 89 euro/tonne CO2 and electricity 192 euro/tonne CO2. For small enterprises and services the excises are around the Stern's social cost of carbon: gas: 78 euro/tonne CO2, electricity: 70 euro/tonne CO2, see Ter Haar (2010). Given the very high value of the social cost of carbon, there appears to be no good reason to raise energy taxes any further at this moment in time. Similarly, Dutch excises on fuels - except those for kerosine and liquified petroleum gas (LPG) - are far above $\$ 85$ per tonne of CO2-emissions: diesel 130 euro, 'red' diesel (diesel for agriculture and shipping) 80 euro, petrol 250 euro, LPG 40 euro, biodiesel 160 euro, ethanol 460 euro, and kerosine is exempt (Ter Haar, 2010). It appears that the excises on these latter fuels have also overshot their Pigouvian values, although it would be good if the government would equalize the excises per tonne CO2 over all fuels. Moreover, the Dutch government levies a CO2-based verhicle tax on new car purchases. Such taxes are also levied in many other countries (OECD, 2010). ${ }^{13}$

In many countries, (greenhouse) farmers, airline companies and shipping companies are

\footnotetext{
${ }^{13}$ It may well be that the use of biofuels generates more rather than less CO2-emissions (see Searchinger et al. 2008) due to large damage done to ecosystems as a result of, for example, deforestation. Biofuels should therefore be subject to higher excises.
} 
exempt from environmentally motivated taxes or receive substantial reductions on their tax bills (OECD, 2010). These exceptions should be abolished. International coordination may be necessary to achieve this, since countries use these tax instruments for tax competition.

The social cost of carbon is not constant, but will rise over time as the rising stock of $\mathrm{CO} 2$ in the atmosphere gradually warms up the earth and creates more environmental damage over time. In addition, more energy-saving technologies and alternative energy sources will be developed. Positive externalities of alternatives for fossil energy sources may therefore rise over time as well. Although energy taxes could be too high at this moment, they still need to display a rising pattern over time (see for example Nordhaus, 2007; Sinn, 2008; Van der Ploeg and Withagen, 2012).

Basically all Western countries are open economies. This implies that no individual country can really do something about global warming on its own. The environment is a global public good, which is not, or only to a limited extent, provided due to its nonrival and non-excludable nature. Consequently, given the absence of a global government, there will be huge coordination failures in securing the efficient level of CO2 emissions. Countries try to free ride on eachother's efforts to reduce global warming. CO2-emissions will be reduced only if all countries in the world commit themselves to binding agreements on carbon taxes or tradable emission permits. As long as individual or groups of countries unilaterally try to reduce energy demand, only the world price of energy falls so as to restore equilibrium on world-energy markets. Reducing energy consumption will then not reduce CO2-emissions, but will only move them to other countries. Therefore, international coordination is vital to realize a global system of tradable emission permits or carbon taxes. Moreover, even global coordination of environmental policies could induce a faster extraction of fossil fuels (Sinn, 2008).

If small-open economies really want to directly contribute to reductions of CO2-emissions, they should not try reducing demand for energy through energy taxes, but rather leave their own fossil fuels in situ. Of course, this will diminish public revenue from gas or oil sales (or from the taxes and excises levied on resources), but directly reduces supply of carbon to world-energy markets.

\section{Corrective taxation of other goods}

Apart from externalities associated with global warming, there are other externalities associated with the consumption or production of certain commodities.

Excises help to bring social cost of meat, poultry, and fish in line with the private costs, and would level the playing field with organic farms. Massive uses of antibiotics, pesticides, growth hormones, fertilizers, and so on, pollute the environment (air, soil, and drinking water), threaten public health, and harm animal well being. Moreover, factory farms are sources of bacterial and viral diseases among living stock and human beings, as break outs of various diseases in recent decades have demonstrated. Therefore, there could be good 
reasons to levy or increase excises on meat, poultry, fish and other products from factory farming.

In addition, the government can use the tax system to internalize externalities associated with unhealthy life styles. Gruber (2010) views obesity as the largest threat for public health in the US. Associated with deteriorating health quality are larger outlays on (public) health-care expenditures. As a result, it could be worthwhile to levy excises on fast food, sugar, and saturated fats. Of course, there could also be reasons for paternalistic government intervention to increase individual well-being if individuals have self-control problems, for example, if individuals have time-inconsistent preferences (Gruber, 2010). Individual health benefits could be substantial if individuals reduce intake of unhealthy foods.

Excises on alcohol and tobacco help to discourage their consumption and align the private costs of the consumption with their social costs. In addition, behavioral economic arguments could justify some public paternalism in setting such excises. However, how big are the externalities of smoking and drinking?

Estimates of the externalities created by smoking are controversial, but only because they suggest that the externalities might actually be positive, rather than negative, despite the extremely high individual cost of smoking in terms of lower life-expectancy. For example, Crawford et al. (2010) refer to calculations made by Viscusi (1995), which demonstrate that smoking has a positive welfare effect in the US. Tollison and Wagner (1992) and Sloan et al. (2004) reach the same conclusion. Also Cnossen (2006) reviews a number of studies and reaches a similar conclusion. The main reason for the positive externality is the premature death caused by smoking. Hence, there are large public savings on public outlays on pensions and health care facilities. These savings outweigh the higher costs of health care, illnesses, fires and forgone tax revenues on labor earnings. The valuation of the damage done to individuals (children) in the vicinity of smokers ('passive smoking') is of course a very complicated matter. Nevertheless, the social cost of smoking - if there is any - appears to be more than sufficiently compensated by high tobacco excises, see also Cnossen (2006) and Crawford et al. (2010). ${ }^{14}$ Finally, the low-income groups are overrepresented among smokers, which renders tobacco excises typically regressive. For all these reasons there is no clear welfare-economic rationale to increase excises on tobacco. Current excises on tobacco could therefore well too high from a strictly welfarist perspective, in some countries, think of the Scandinavian countries, but also the Netherlands.

The external costs of alcohol are much less controversial. In principle, the direct individual damage to health (premature mortality), lower earnings and lower quality of life cannot be treated as an external cost unless the government has paternalistic objectives. Cnossen (2007) summarizes numerous studies calculating the external costs of alcohol. External costs are caused by a relatively small group of heavy drinkers: traffic accidents,

\footnotetext{
${ }^{14}$ In addition, governments all around the world not only use excises to steer behavior of smokers, but also use regulation by outlawing smoking in public places, bars, restaurants, and so on. Smoking bans act as implicit taxes on smoking.
} 
criminal behavior, (home) violence and public costs of health care. The external costs vary from country to country. The unweighted country average over 7 EU-countries and 4 Anglo-Saxon countries is 20 euro per liter of pure alcohol consumption when only the direct tangible costs are calculated (health care, criminal justice system, traffic accidents). The unweighted country average is 35 euro per liter of pure alcohol consumption when (production) losses on account of absenteeism, unemployment and premature mortality are included as well. Note, however, that many of these costs cannot be regarded as pure external costs, since they include a large fraction of private costs as well.

Cnossen (2007) demonstrates that the external costs of alcohol use are larger than the revenue from alcohol excises in all countries under his consideration (7 EU countries plus US, Canada, Australia and New Zealand), except for Finland. In other words, alcohol excises are not set at the optimal, Pigouvian level. ${ }^{15}$ For example, in the Netherlands current alcohol excises are only 1.1 euro per liter of pure alcohol in beer, and around 6 euro per liter of pure alcohol in wine and spirits (Dutch Ministry of Finance, 2011). In other words, Dutch alcohol excises are by far not set at the optimal, Pigouvian level. Higher excises on alcohol can therefore be defended for Pigouvian reasons in many countries, with the possible exception of the Scandinavian countries that already have very high excises on alcohol.

The distribution of alcohol excises could be an issue, since damage done by a relatively small group of heavy drinkers is paid for by a majority of moderate alcohol consumers. Ideally, the government would like to levy a non-linear tax on alcohol, which is increasing with alcohol consumption. Due to arbitrage problems such a policy is not feasible. In order to shift the costs more to the problem drinkers, specific regulation might also be useful, for example, through large fines and losses of driving licenses when caught drinking and driving, large fines with the ultimate loss of licenses when alcohol is sold to minors and drunks, severe penalties and high fines for alcohol-related violence and disturbing public safety.

\section{Conclusions}

This section derives a number of policy recommendations. These recommendations follow from an attempt to strictly adhere to a welfare-based optimal tax analysis. Naturally, these recommendations are as good as the analysis that underlies them. Certainly, one can have different views on important assumptions that are used to derive these conclusions, which also implies that one does not need to share all policy recommendations. Some conclusions also depend on some elements of judgment or 'educated guessing' if either theoretical analysis or empirical evidence is missing. Only more future research can bring us closer to make more informed recommendations.

\footnotetext{
${ }^{15}$ Cnossen's (2007) analysis applies to data from 2003. Meanwhile countries could have raised alcohol excises to more Pigouvian levels.
} 
When it comes to the taxation of labor income, taxes should be non-linear. A flat tax is never optimal, irrespective of political preferences for redistribution. Compared to a non-linear tax, a flat tax does not generate more employment for the same income redistribution, is not simpler and does not result in fewer political distortions. The only advantage of a flat tax - less arbitrage between tax bases, between tax payers and over time - only materialize if all effective marginal tax rates are constant and equal, i.e. when all income-dependent programs are completely abolished.

The optimal non-linear tax schedule typically follows a U-shape with income. Optimal marginal tax rates at the bottom end of the earnings distribution are very high, in the order of 60-80 percent. Hence, the 'poverty trap' is part of the optimal tax system. Effective marginal tax rates should decline towards the modal-income group, and may increase thereafter to top rates of around 50 percent. Exact levels of tax rates depend on political preferences for redistribution. However, the more 'left-wing' political preferences are, the smaller is the increase of marginal tax rates after modal earnings. The stronger is the political weight given to the middle-income groups, the more tax rates should increase after modal earnings.

Marginal tax rates larger than 100 percent are generally not optimal, unless the government engages in a lot of monitoring of work, training and job-search effort of nonparticipants. Hence, simplifying and streamlining income-dependent arrangements should preferably reduce marginal tax burdens below 100 percent. The Earned Income Tax Credit (EITC) is a useful device to reduce distortions on the extensive margin (i.e. participation), but it redistributes resources away from the poor. An optimal EITC does not shift the marginal tax burden too much to the densely populated middle-income groups to avoid large distortions on the intensive labor supply margin.

Tax credits or subsidies for rent, health-care costs and other commodities should preferably be replaced by refundable tax-credits or a negative income tax so as to avoid distortions in consumption demand of these commodities, while not sacrificing on the distributional tasks of the tax system. As long as there are no distributional changes, there are no reductions in labor market distortions either. Minimum wages are typically not an optimal redistributional device; it is often better to support low-income households using wage subsidies or tax credits like the EITC.

The optimal tax system is a dual-tax system where labor and capital incomes are separately taxed. Neither a synthetic income tax, nor a pure consumption/expenditure tax can be defended on welfare-economic grounds. Capital income should be taxed for efficiency reasons, as taxing capital income reduces the distortions created by the nonlinear labor-income tax. In particular, capital-income taxes can stimulate labor supply over the life-cycle, boost the retirement age, stimulate investments in human capital, avoid tax shifting between labor and capital income, tax rents, and help to correct failing capital and insurance markets. Capital income taxes are also useful as a redistributional device over and above the redistribution that can be organized with labor-income taxes. Capital incomes correlate with earning ability. Capital incomes are labor incomes in disguise 
through tax shifting and entrepreneurial efforts. Capital incomes are the result of initial wealth differences. And, capital incomes contain above normal returns to investments (luck, informational advantages, monopoly profits, etc).

All relevant capital incomes should be included in the capital-income tax regime, such as interest on savings, asset returns, returns on pension savings and housing, and returns on assets held in small firms or closely-held companies. Capital incomes should be taxed at a flat rate to avoid tax arbitrage between different sources of capital incomes. There is no need for a wealth tax as long as realized capital gains are taxed. Pension savings can be made deductible for the labor-income tax, as long as pension benefits are taxed under the labor-income tax and accrual of pension wealth is taxed under the capital-income tax.

Owner-occupied housing should be seen as an asset, subject to the same tax treatment as all other assets. On the one hand, this implies that costs of acquiring the assets, most importantly mortgage rent, are deductible from the capital-income tax. On the other hand, this also implies that imputed rent should be taxed. The imputed rent should be equal to the normal return on housing assets. The government may want raise the tax on housing through (local) property taxes so as to efficiently tax scarcity rents (location, land, benefit tax for local public goods). Realized capital gains on houses should be taxed as ordinary capital gains. There should be no transaction taxes or stamp duties on housing sales.

Uniform commodity taxes (VAT) are not desirable, both on theoretical and empirical grounds. Theoretically, goods that are more complementary to leisure should be taxed at higher rates, whereas goods more complementary to work should be taxed at lower rates. Empirical evidence shows that commodity demand patterns can only be systematically related to labor supply behavior in well-defined cases. Arbitrage, administrative and compliance costs associated with differentiated commodity taxes are substantial and it is not clear whether commodity tax differentiation brings substantial welfare gains, if at all. There are no good economic reasons to exempt many goods from value added taxes and these exemptions should be avoided as much as possible.

Differentiated VAT-rates between luxury goods and necessary goods have no clear rationale either as long as the government can levy a non-linear income tax. The distinction in VAT-rates can be abolished while adjusting the income tax at the same time to neutralize the distributional effects. A generic low tax rate on labor-intensive services may not be desirable. It is generally better to lower taxes on low-income earners to promote employment of low-income earners. Specific instruments targeted at close substitutes for household production (e.g. child-care facilities) are better than generic instruments to discourage informal-sector employment.

The primary goal of environmental taxes is to internalize the negative externalities associated with polluting consumption. Environmental taxes should not be motivated to raise public revenue or to 'green' the tax system. Differentiated commodity taxation is not desirable from a revenue-raising perspective. The social cost of carbon will rise over time, and energy and fuel taxes should increase as the earth warms up and the environment deteriorates further. Until no global agreements are reached, unilateral efforts 
small countries are not effective to combat global warming. Only international agreements to which all countries subject themselves can solve the coordination failure in providing the global public good of avoiding a climate disaster.

Excises on factory-farming products are needed to internalize adverse consequences of factory farming for human health, animal well being and the environment. It is generally efficient to increase alcohol excises as the social cost of drinking is not sufficiently compensated by revenue from alcohol excises in many countries. Regulation to reduce alcohol abuse is also desirable so as to let the 'polluter' pay for the damage done, since alcohol excises cannot be targeted well at those individuals causing most alcohol-related damage. Tobacco excises should not be increased as the external damage of smoking - if there is any - is more than compensated by current level of tobacco excises. Plans to increase tobacco excises further cannot be supported on purely welfare-economic grounds.

\section{References}

Aiyagari, S. Rao (1994), "Optimal Capital Income Taxation with Incomplete Markets, Borrowing Constraints and Constant Discounting", Research Department Working Paper No. 508, Minneapolis: Federal Reserve Bank of Minneapolis.

Aiyagari, S. Rao (1995), "Optimal Capital Income taxation with Incomplete Markets, Borrowing Constraints, and Constant Discounting", Journal of Political Economy, 103, (6), 1158-1175.

Akerlof, George A. (1976), "The Economics of the Caste and of the Rat Race and Other Woeful Tales", Quarterly Journal of Economics, 90, (4), 599-617.

Akerlof, George A. (1978), "The Economics of "Tagging" as Applied to the Optimal Income Tax, Welfare Programs, and Manpower Planning", American Economic Review, 68, (1), 8-19.

Alesina, Alberto F., Edward L. Glaeser and Bruce Sacerdote (2005), "Work in the US and Europe: Why so Different?", NBER Macroeconomic Annuals, 2, 1-64.

Allen, Stephen P. (1987), "Taxation, Redistribution, and the Minimum Wage: A Theoretical Analysis", Quarterly Journal of Economics, 102, (3), 447-490.

Allers, Maarten A. (1994), Administrative and Compliance Costs of Taxation and Public Transfers in the Netherlands, Groningen: Wolters Noordhoff.

Andrews, Dan, Aida Caldera Sánchez and Åsa Johansson (2011), "Housing Markets and Structural Policies in OECD Countries", OECD Economics Department Working Papers, No. 836, Paris: OECD. 
Atkinson, Anthony B., Thomas Piketty and Saez Emmanuel (2011), "Top Incomes in the Long Run of History", Journal of Economic Literature, 49, (1), 3-71.

Atkinson, Anthony B., and Joseph E. Stiglitz (1976), "The Design of Tax Structure: Direct versus Indirect Taxation", Journal of Public Economics, 6, (1-2), 55-75.

Attanasio, Orazio P., and Guilermo Weber (2010), "Consumption and Saving: Models of Intertemporal Allocation and their Implications for Public Policy", NBER Working Paper 15756, Cambridge-MA: NBER.

Auerbach, Alan, Michael P. Devereux and Helen Simpson (2010), "Taxing Corporate Income", in: James A. Mirrlees et al. (eds), The Mirrlees Review. Dimensions of Tax Design, ch. 9, Oxford: Oxford University Press, 837-893.

Banks, James, and Peter A. Diamond (2010), "The Base for Direct Taxation", in: James A. Mirrlees et al. (eds), The Mirrlees Review. Dimensions of Tax Design, ch. 6, Oxford: Oxford University Press, 548-648.

Barro, Robert J. (1974), “Are Government Bonds Net Wealth?", Journal of Political Economy, 82, (6), 1095-1117.

Bernheim, B. Douglas, and Antonio Rangel (2009), "Beyond Revealed Preference: ChoiceTheoretic Foundations for Behavioral Welfare Economics", Quarterly Journal of Economics, 124, (1), 51-104.

Blundell, Richard, Antoine Bozio and Guy Laroque (2011), "Extensive and Intensive Margins of Labour Supply: Working Hours in the US, UK and France", American Economic Review, 101, (3), 482-486.

Blundell, Richard, and Thomas MaCurdy (1999), "Labor Supply: A Review of Alternative Approaches", in: Orley Ashenfelter and David Card (eds.), Handbook of Labor Economics, Vol 3A, Amsterdam: Elsevier North Holland, 1559-1695.

Blundell, Richard, and Andrew Shephard (2011), "Employment, Hours of Work and the Optimal Taxation of Low Income Families", Review of Economic Studies, 79, (2), 481-510.

Boadway, Robin, Emma Chamberlain and Carl Emmerson (2010), "Taxation of Wealth and Wealth Transfers", in: James A. Mirrlees et al. (eds), The Mirrlees Review. Dimensions of Tax Design, ch. 8, Oxford: Oxford University Press, 737-814.

Boadway, Robin, and Laurence Jacquet (2008), "Optimal Marginal and Average Taxes under Maximin", Journal of Economic Theory, 143, (1), 425-441.

Boadway, Robin, and Jean-Francois Tremblay (2012), "Optimal Income Taxation and the Labour Market: An Overview", CESifo Economic Studies, forthcoming. 
Boskin, Michael J., and Eytan Sheshinski (1983), "Optimal Tax Treatment of the Family: Married Couples", Journal of Public Economics, 20, (3), 281-297.

Bovenberg, A. Lans, and Bas Jacobs (2005), "Redistribution and Education Subsidies are Siamese Twins", Journal of Public Economics, 89, (11-12), 2005-2035.

Bovenberg, A. Lans, and Ruud A. de Mooij (1994), "Environmental Levies and Distortionary Taxation", American Economic Review, 84, (4), 1085-1089.

Bovenberg, A. Lans, and Coen Teulings (2006), "Vlaktaks: Haken en Ogen", in: Flip de Kam and Arie Ros, De Vlaktaks. Naar een Inkomstenbelasting met een Uniform Tarief?, Den Haag: Wim Drees Stichting voor Openbare Financiën.

Caldera Sánchez, Aida, and Åsa Johansson (2011), "The Price Responsiveness of Housing Supply in OECD Countries", OECD Economics Department Working Papers, No. 837, OECD Publishing.

Carneiro, Pedro, and James J. Heckman (2003), "Human Capital Policy", in James J. Heckman and Alan B. Krueger (eds.), Inequality in America: What Role for Human Capital Policy?, Cambridge-MA: MIT Press.

Chamley, Christophe (1986), "Optimal Taxation of Capital Income in General Equilibrium With Infinite Lives", Econometrica, 54, (3), 607-622.

Christiansen, Vidar (2012), "Optimal Participation Taxes", CESifo Working Paper No. 3941, Munich: CESifo.

Christiansen, Vidar, and Matti Tuomala (2008), "On Taxing Capital Income with Income Shifting", International Tax and Public Finance, 15, (4), 527-545.

Cnossen, Sijbren (2006), "Tobacco Taxation in the European Union", FinanzArchiv, 62, (2), 305-322.

Cnossen, Sijbren (2007), "Alcohol Taxation and Regulation in the European Union", International Tax and Public Finance, 14, (6), 699-732.

Cnossen, Sijbren (2010), "Value-Added Tax and Excises: Commentary", in: James A. Mirrlees et al. (eds), The Mirrlees Review. Dimensions of Tax Design, ch. 4, Oxford: Oxford University Press, 370-386.

Cnossen, Sijbren, and A. Lans Bovenberg (1999), "Fundamental Tax Reform in the Netherlands", International Tax and Public Finance, 8, (4), 471-484.

Conesa, Juan C., Sagiri Kitao and Dirk Krueger (2009), "Taxing Capital? Not a Bad Idea After All", American Economic Review, 99, (1), 25-48. 
Correia, Isabel H. (1996), "Should Capital Income be Taxed in the Steady State", Journal of Public Economics, 60, (1), 147-151.

Crawford Ian, Michael Keen and Stephen Smith (2010), "Value Added Taxes and Excises", in: James A. Mirrlees et al. (eds), The Mirrlees Review. Dimensions of Tax Design, ch. 4, Oxford: Oxford University Press, 275-422.

Currie, Janet, and Firouz Gahvari (2008), "Transfers in Cash and In-Kind: Theory Meets the Data", Journal of Economic Literature, 46, (2), 333-383.

Deaton, Angus S. (1979), "Optimally Uniform Commodity Taxes", Economics Letters, 2, (4), 357-361.

Diamond, Peter A. (1980), "Income Taxation with Fixed Hours of Work", Journal of Public Economics, 13, (1), 101-110.

Diamond, Peter A. (1998), "Optimal Income Taxation: An Example with a U-Shaped Pattern of Optimal Marginal Tax Rates", American Economic Review, 88, (1), 8395.

Diamond, Peter A., and James A. Mirrlees (1971a), "Optimal Taxation and Public Production I: Production Efficiency", American Economic Review, 61, (1), 8-27.

Diamond, Peter A., and James A. Mirrlees (1971b), "Optimal Taxation and Public Production II: Tax Rules", American Economic Review, 61, (3), 261-278.

Diamond, Peter A., and James A. Mirrlees (1978), "A Model of Social Insurance with Variable Retirement", Journal of Public Economics, 10, (3), 295-336.

Diamond, Peter A., and James A. Mirrlees (1986), "Payroll-Tax Financed Social Insurance with Variable Retirement", Scandinavian Journal of Economics, 88, (1), 25-50.

Diamond, Peter A., and Emmanuel Saez (2011), "The Case for a Progressive Income Tax", Journal of Economic Perspectives, 25, (4), 165-190.

Diamond, Peter A., and Johannes Spinnewijn (2011), "Capital Income Taxes with Heterogeneous Discount Rates", American Economic Journal: Policy, 3, (4), 52-76.

Dutch Ministry of Finance (2011), www.minfin.nl.

Eaton, Jonathan, and Harvey S. Rosen (1980a), "Labor Supply, Uncertainty, and Efficient Taxation", Journal of Public Economics, 14, (3), 365-374.

Eaton, Jonathan, and Harvey S. Rosen (1980b), "Optimal Redistributive Taxation and Uncertainty", Quarterly Journal of Economics, 95, (2), 357-364. 
Erosa, Andrés, and Martin Gervais (2002), "Optimal Taxation in Life-Cycle Economies", Journal of Economic Theory, 105, (2), 338-369.

Ewijk, Casper van, Bas Jacobs and Ruud A. de Mooij (2007), "Welfare Effects of Fiscal Subsidies on Home Ownership in the Netherlands", De Economist, 150, (3), 323-336.

Friedman, Milton (1962), Capitalism and Freedom, Chicago: Chicago University Press.

Fuest, Clemens, and Alfons Weichenrieder (2002), "Tax Competition and Profit Shifting: On the Relationship between Personal and Corporate Tax Rates", Ifo Studien: Zeitschrift für Empirische Wirtshaftsforschung, 48, 611-632.

Fullerton, Don, Andrew Leicester and Stephen Smith (2010), "Environmental Taxes", in: James A. Mirrlees et al. (eds), The Mirrlees Review. Dimensions of Tax Design, ch. 4, Oxford: Oxford University Press, 422-518.

Gerritsen, Aart, and Bas Jacobs (2011), "Optimal Minimum Wages and Optimal Redistribution in Competitive Labor Markets with Endogenous Skill Formation", mimeo: Erasmus University Rotterdam.

Gerritsen, Aart, and Bas Jacobs (2012), "Optimal Redistribution: Minimum Wages, Unemployment, and Education", mimeo: Erasmus University Rotterdam.

Gielen, Miriam, Joke Goes, Marcel Lever and Rocus van Opstal (2009), "Ontwikkeling en Verdeling van de Marginale Druk in 2001-2011", CPB Document No. 195, Den Haag: CPB.

Golosov, Mikhail, Nayarana Kocherlakota and Aleh Tsyvinski (2003), "Optimal Indirect and Capital Taxation", Review of Economic Studies, 70, (3), 569-587.

Gordon, Roger H., and Wojciech Kopczuk (2010), "The Choice of the Personal Income Tax Base", mimeo: Columbia University.

Griffith, Rachel, James Hines and Peter Birch Sørensen (2010), "International Capital Taxation", in: James A. Mirrlees et al. (eds), The Mirrlees Review. Dimensions of Tax Design, ch. 10, Oxford: Oxford University Press, 914-996.

Gruber, Jonathan, and David Wise (1999), Social Security and Retirement around the World, Chicago: Chicago University Press.

Gruber, Jonathan, and David Wise (2002), "Social Security and Retirement around the World: Microestimation", NBER Working Paper No. 9407, Cambridge-MA: NBER.

Gruber, Jonathan (2010), "Value-Added Tax and Excises: Commentary", in: James A. Mirrlees et al. (eds), The Mirrlees Review. Dimensions of Tax Design, ch. 4, Oxford: Oxford University Press, 407-422. 
Guesnerie, Roger, and Kevin Roberts (1987), "Minimum Wage Legislation as a SecondBest Policy", European Economic Review, 31, (1-2), 490-498.

Hall, Robert E., and Alvin Rabushka (1983), Low Tax, Simple Tax, Flat Tax, New York: McGraw-Hill.

Hubbard, R. Glenn, and Kenneth L. Judd (1986), "Liquidity Constraints, Fiscal Policy, and Consumption", Brookings Papers on Economic Activity, 1, 1-59.

IMF (2011), Global Financial Stability Report, Washington DC: IMF.

Jacobs, Bas (2009a), "The Marginal Cost of Public Funds and Optimal Second-Best Policy Rules", mimeo: Erasmus University Rotterdam.

Jacobs, Bas (2009b), "A Life-Cycle Theory of Human Capital Formation, Pension Saving, and Retirement", paper prepared for the ESF Forward Looks Conference Dublin, November 8 2008, and The Hague, April 222009.

Jacobs Bas (2010), "Een Economische Analyse van een Optimaal Belastingstelsel voor Nederland", in: Studiecommissie Belastingstelsel (2010), "Continuïteit en Vernieuwing. Een Visie op het Belastingstelsel ", Den Haag: Ministry of Finance.

Jacobs, Bas (2011), "From Optimal Tax Theory to Applied Tax Policy", The Research Forum on Taxation 'Skatteforum', June 7-8, Moss, Norway, 2011.

Jacobs, Bas, and A. Lans Bovenberg (2010), "Human Capital and Optimal Positive Taxation of Capital Income", International Tax and Public Finance, 17, (5), 451-478.

Jacobs, Bas, and Lans Bovenberg (2011), "Optimal Taxation of Human Capital and the Earnings Function", Journal of Public Economic Theory, 13, (6), 957-971.

Jacobs, Bas, and Ruud A. de Mooij (2011), "Pigou Meets Mirrlees: On the Irrelevance of Tax Distortions for the Second-Best Pigouvian Tax", CESifo Working Paper No. 3342, Munich: CESifo.

Jacobs, Bas, and Dirk Schindler (2012), "On the Desirability of Taxing Capital Income in Optimal Social Insurance", Journal of Public Economics, 96, (9-10), 853-868.

Jacobs, Bas, and Honyang Yang (2012), "Optimal Taxation of Human Capital and Credit Constraints", mimeo: Erasmus Universiteit Rotterdam.

Jacquet, Laurence Etienne Lehman and Bruno van der Linden (2010), "The Optimal Marginal Tax Rates with both Extensive and Intensive Responses", IRES Working Paper 2010-33, Paris. 
Judd, Kenneth L. (1985), "Redistributive Taxation in a Simple Perfect Foresight Model", Journal of Public Economics, 28, (1), 59-83.

Judd, Kenneth L. (1999), "Optimal Taxation and Spending in General Competitive Growth Models", Journal of Public Economics, 71, (3), 1-26.

Kanbur, Ravi, Jukka Pirttilä and Matti Tuomala (2006), "Non-Welfarist Optimal Taxation and Behavioral Public Economics", Journal of Economic Surveys, 20, (5), 849868.

Kaplow, Louis and Steven Shavell (2002), Fairness versus Welfare, Cambridge-MA: Harvard University Press.

Kleven, Henrik Jacobsen, Martin Knudsen, Claus Thustrup Kreiner, Søren Pedersen and Emmanuel Saez (2011), "Unwilling or Unable to Cheat? Evidence from a Tax Audit Experiment in Denmark", Econometrica, 79, (3), 651-692.

Layard, Richard (1980), "Human Satisfactions and Public Policy", Economic Journal, 90, (360), 737-750.

Lee, David, and Emmanuel Saez (2012), "Optimal Minimum Wage Policy in Competitive Labor Markets", Journal of Public Economics, 96, (9-10), 739-749.

Lindbeck, Assar, and Sven Nyberg (2006). "Raising Children to Work Hard: Altruism, Work Norms and Social Insurance", Quarterly Journal of Economics, 121, (4), 14731503 .

Mankiw, Gregory N., Matthew Weinzierl and Danny Yagan (2009), "Optimal Taxation in Theory and Practice", Journal of Economic Perspectives, 23, (4), 147-174.

Meghir Costas, and David Phillips (2010), "Labour Supply and Taxes", in: James A. Mirrlees et al. (eds), The Mirrlees Review. Dimensions of Tax Design, ch. 3, Oxford: Oxford University Press, 202-274.

Mirrlees, James A. (1971), "An Exploration in the Theory of Optimum Income Taxation", Review of Economic Statistics, 38, (2), 175-208.

Mirrlees, James A. (1976), "Optimal Tax Theory: A Synthesis", Journal of Public Economics, 6, (4), 327-358.

Mirrlees Review (2011), Tax by Design, Oxford: Oxford University Press.

Mooij, Ruud A. de (2008), "Reinventing the Dutch Tax-Benefit System: Exploring the Frontier of the Equity-Efficiency Trade-Off", International Tax and Public Finance, $15,(1), 87-104$. 
Mooij, Ruud A. de, and Gaëtan Nicodème (2008), "Corporate Tax Policy and Incorporation in the EU", International Tax and Public Finance, 15, (4), 478-498.

Nishiyama, Shinichi, and Kent Smetters (2005), "Consumption Taxes and Economic Efficiency with Idiosyncratic Wage Shocks", Journal of Political Economy, 113, (5), $1088-1115$.

Nordhaus, William D. (2007), "A Review of the Stern Review on the Economics of Climate Change", Journal of Economic Literature, 45, (3), 686-702.

OECD (2010), Taxation, Innovation and the Environment, OECD: Paris.

OECD (2011a), "Taxation and Employment", OECD Tax Policy Studies, No. 21, Paris: OECD.

OECD (2011b), Going for Growth, Paris: OECD.

OECD (2011c), Pensions at a Glance, Paris: OECD.

Pigou, Arthur C. (1920), The Economics of Welfare, London: MacMillan.

Pirttilä, Jukka, and Ilpo Suoniemi (2009), "Public Provision, Commodity Demand, and Hours of Work: An Empirical Analysis", CESifo Working Paper No. 3000, Munich: CESifo.

Ploeg, Frederick van der, and Cees Withagen (2012), "Is there Really a Green Paradox?", Journal of Environmental Economics and Management, 64, (3), 342-363.

Poterba, James M. (1984), "Tax Subsidies to Owner-Occupied Housing: An Asset-Market Approach", Quarterly Journal of Economics, 99, (4), 729-752.

Reis, Catarina (2009), "Entrepreneurial Labor and the Taxation of Capital", mimeo: Universidade Católica Portuguesa.

Saez, Emmanuel (2001), "Using Elasticities to Derive Optimal Income Tax Rates", Review of Economic Studies, 68, (1), 205-229.

Saez, Emmanuel (2002a), "Optimal Income Transfer Programs: Intensive Versus Extensive Labor Supply Responses", Quarterly Journal of Economics, 117, (3), 1039-1073.

Saez, Emmanuel (2002b), "The Desirability of Commodity Taxation Under Non-Linear Income Taxation and Heterogeneous Tastes", Journal of Public Economics, 83, (2), 217-230.

Sandmo, Agnar (1974), "A Note on the Structure of Optimal Taxation", American Economic Review, 64, (4), 701-706. 
Sandmo, Agnar (1975), "Optimal Taxation in the Presence of Externalities", Scandinavian Journal of Economics, 77, (1), 86-98.

Searchinger, Timothy, Ralph Heimlich, R. A. Houghton, Fengxia Dong, Amani Elobeid, Jacinto Fabiosa, Simla Tokgoz, Dermot Hayes and Tun-Hsiang Yu (2008), "Use of U.S. Croplands for Biofuels Increases Greenhouse Gases Through Emissions from Land-Use Change", Science, 319, (5867), 1238-1240.

Sen, Amartya (1985), Commodities and Capabilities, Oxford: Oxford University Press.

Sinn, Hans-Werner (2008), "Public Policies against Global Warming", International Tax and Public Finance, 15, (4), 360-394.

Sloan, Frank A., Jan Ostermann, Christopher Conover, Donald H. Taylor, Jr. and Gabriel Picone (2004), The Price of Smoking, Cambridge-MA: MIT-Press.

Sørensen, Peter B. (1997), "Public Finance Solutions to the European Unemployment Problem", Economic Policy, 12, (25), 221-264.

Sørensen, Peter B. (2009), "Dual Income Taxes: a Nordic Tax System", Economic Policy Research Unit, University of Copenhagen.

Stern, Nicholas H. (2007), The Economics of Climate Change: The Stern Review, Cambridge and New York: Cambridge University Press.

Ter Haar, Bernard (2010), "Nieuwe Paden voor Vergroening”, in: Studiecommissie Belastingstelsel (2010), "Continuïteit en Vernieuwing. Een Visie op het Belastingstelsel", Den Haag: Ministry of Finance.

Tol, Richard S.J. (2008), "The Social Cost of Carbon: Trends, Outliers and Catastrophes", Economics, 2, 2008-25, www.economics-ejournal.org.

Tollison, Robert D., and Richard E. Wagner (1992), The Economics of Smoking, NorwellMA: Kluwer Academic Publishers.

Tuomala, Matti (1984), "On the Optimal Income Taxation: Some Further Numerical Results", Journal of Public Economics, 23, (3), 351-366.

Viscusi, W. Kip (1995), "Cigarette Taxation and the Social Consequences of Smoking", Tax Policy and the Economy, 9, 51-101.

Yoo, Kwang-Yeol, and Alain De Seres (2005), "Tax Treatment of Private Pension Savings in OECD Countries", OECD Economic Studies, 39, 2004/2.

Zoutman, Floris, Bas Jacobs and Egbert Jongen (2011), "Optimal Redistributive Taxes and Redistributive Preferences in the Netherlands", mimeo: Erasmus University Rotterdam/CPB Netherlands Bureau for Economic Policy Research. 
Zoutman, Floris, and Bas Jacobs (2012), "Optimal Redistribution and Optimal Monitoring of Labor Effort", mimeo: Erasmus University Rotterdam. 